\title{
How to Choose a Constitutional Theory
}

\section{Citation}

Richard H. Fallon, Jr., How to Choose a Constitutional Theory, 87 Calif. L. Rev. 535 (1999).

\section{Published Version}

http://scholarship.law.berkeley.edu/californialawreview/vol87/iss3/2/

\section{Permanent link}

http://nrs.harvard.edu/urn-3:HUL.InstRepos:12956282

\section{Terms of Use}

This article was downloaded from Harvard University's DASH repository, and is made available under the terms and conditions applicable to Other Posted Material, as set forth at http:// nrs.harvard.edu/urn-3:HUL.InstRepos:dash.current.terms-of-use\#LAA

\section{Share Your Story}

The Harvard community has made this article openly available.

Please share how this access benefits you. Submit a story.

\section{Accessibility}




\section{California Law Review}

Volume 87 | Issue 3

Article 2

May 1999

\section{How to Choose a Constitutional Theory}

Richard H. Fallon Jr.

Follow this and additional works at: http://scholarship.law.berkeley.edu/californialawreview

\section{Recommended Citation}

Richard H. Fallon Jr., How to Choose a Constitutional Theory, 87 CAL. L. Rev. 535 (1999).

Available at: http://scholarship.law.berkeley.edu/californialawreview/vol87/iss3/2

This Article is brought to you for free and open access by the California Law Review at Berkeley Law Scholarship Repository. It has been accepted for inclusion in California Law Review by an authorized administrator of Berkeley Law Scholarship Repository. For more information, please contact jcera@law.berkeley.edu. 


\title{
How to Choose a Constitutional Theory
}

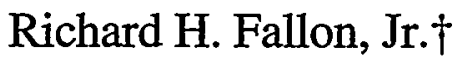

\section{TABLE OF CONTENTS}

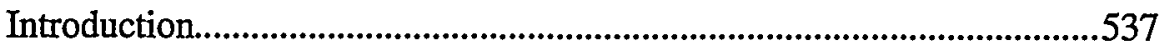

I. The Inherently Value-Laden Choice Between Text-Based and Practice-Based Theories...........................................................540

A. The Nature of Constitutional Theories ......................................540

1. Text-Based Theories ...........................................................541

2. Practice-Based Theories....................................................542

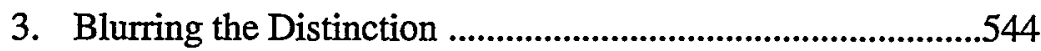

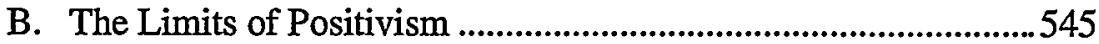

II. Three Shared Evaluative Criteria....................................................549

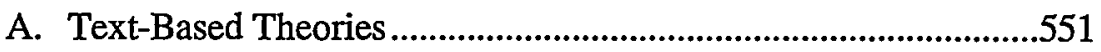

B. Practice-Based Theories .........................................................554

C. Continuing Disagreement and an Agenda for Further

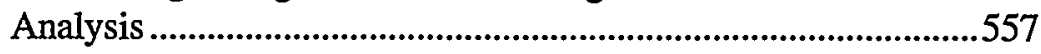

D. Assessing the Prevailing Criteria..................................................558

1. The Relevance of the Prevailing Criteria...............................558

2. Other Criteria ..........................................................................559

III. Formal Theories, Substantive Criteria, and the Pertinence of Who Occupies the Bench...........................................................562

A. Substantive and Formal Theories ............................................562

B. Historical Contingency and Constitutional Theory ......................568

C. Meeting an Objection ..............................................................570

IV. Who Needs Constitutional Theory?.............................................572

A. The Perils of Pragmatisin ........................................................573

B. Do Judges Need Constitutional Theory?......................................574

Copyright @ 1999 California Law Review, Inc.

+ Professor of Law, Harvard University. I have benefitted from comments by Sharon Dolovich, Dan Farber, Joel Goldstein, Larry Lessig, Joe Liu, Dan Meltzer, Frank Michelman, Henry Monaghan, Connie Rosati, Larry Sager, Fred Schauer, David Shapiro, and participants in legal theory workshops at Harvard Law School and at the School of Law, University of California, Berkeley (Boalt Hall). 


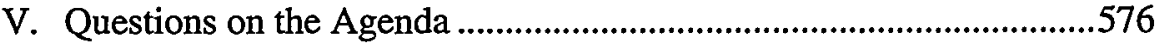

A. Who Should Choose?

.576

B. What Are the Appropriate Time Horizons?

578

Conclusion 


\title{
How to Choose a Constitutional Theory
}

\author{
Richard H. Fallon, Jr.
}

People concerned about constitutional law confront a large number of competing constitutional theories, which offer conflicting accounts of how judges should interpret and apply the Constitution. Assessment of such theories needs to be based partly on normative grounds. Moreover, there is a surprising degree of implicit agreement among constitutional theorists about the criteria that a constitutional theory ought to satisfy. Besides "fitting" either the text of the written Constitution or surrounding constitutional practice, constitutional theories should be judged based on their capacity to (i) maintain the rule of law, (ii) preserve fair opportunity for political democracy, and (iii) protect a morally and politically acceptable set of substantive rights. Determining which constitutional theory would best promote these goals requires a partly instrumental calculation, including an assessment of who our judges and Justices are likely to be. Nonetheless, the need to select a theory on instrumental grounds does not justify unprincipled, case-by-case manipulation. A good constitutional theory should impose constraints on those who accept it.

\section{INTRODUCTION}

Anyone who cares about constitutional law confronts a large and proliferating number of constitutional theories, by which I mean theories about the nature of the United States Constitution and how judges should interpret and apply it.' On the surface, the competing theories not only

1. Cf. Richard A. Posner, Against Constitutional Theory, 73 N.Y.U. L. REv. 1, 1 (1998) ("Constitutional theory, as I shall use the term, is the effort to develop a generally accepted theory to guide the interpretation of the Constitution of the United States."). A by no means exhaustive list of prominent examples of constitutional theories includes those advanced by 1 BRUCE ACKERMAN, WE the People (1991); 2 Bruce Ackerman, We the People (1998); Raoul Berger, Government by Judiciary (1977); Alexander M. Bickel, The Least Dangerous Branch (1962); Philip BobBitT, Constitutional INTERpretation (1991); ROBERT H. BORK, The TeMpting of AMerica (1990); Jesse H. Choper, Judicial Review and the National Political Process (1980); Ronald

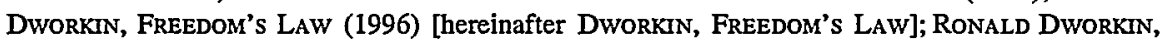

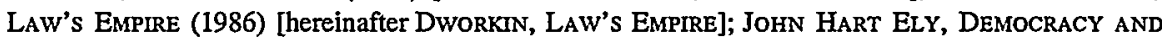
Distrust (1980); Richard A. Epstein, Takings: Private Property and the Power of Eminent Domain (1985); David A.J. Richards, Toleration and the Constitution (1986); LauRence H. Tribe \& Michael C. Dorf, ON Reading the Constitution (1991); Harry H. Wellington, INTERPRETING THE CONSTIrUTION (1990); Lawrence Lessig, Fidelity in Translation, 71 Tex. L. REv. 
assert diverse substantive claims, but also appear to make different assumptions abont the criteria that a constitutional theory ought to satisfy. For example, some text-based theories claim validity on the ground that they "fit" the written Constitution uniquely well. ${ }^{2}$ By contrast, what I call "practice-based theories" assert their superiority because they better fit or explam a constitutional "practice" im which judges sometimes decide cases based on considerations that go beyond the constitutional text. ${ }^{3}$

A second divide among constitutional theories separates those that are "substantive" from those that are more "formal" or "methodological." Substantive theories seek to identify substantive values that constitutional adjudication ought to advance. Examples include theories that call for decision making to promote natural law ${ }^{4}$ or Rawlsian liberalism. ${ }^{5}$ In contrast, formal theories prescribe methodologies that should be used in constitutional decision making, but do not purport to identify substantive values by which outcomes should be tested. ${ }^{6}$ For example, "originalists" maintam that courts should generally interpret constitutional language to accord with the "original understanding" of those who wrote and ratified it, regardless of the substantive values that the original understanding might reflect. 7

Given the variety of constitutional theories, and perhaps especially the divergent methodological assumptions that appear to lie behind them, by what criteria should anyone choose which theory, or which type of theory, to embrace? In seeking to answer this question, I advance four principal claims in this Article. First, as I argue in Part I, the choice of a constitutional theory must be based at least partly on considerations that are external to the constitutional text. The written Constitution, by itself, cannot determine the correctness of any particular theory of constitutional interpretation. Selection must reflect a judgment about which theory would yield the best outcomes, as measured agamst relevant criteria.

1165 (1993); Frank Michelman, Law's Republic, 97 YALE L.J. 1493, 1520 (1988); and David A. Strauss, Common Law Constitutional Interpretation, 63 U. CHI. L. REv. 877 (1996).

2. See, e.g., Bork, supra note 1, at 1-5 (urging judges not to stray beyond the text of the Constitutiou in deciding constitutional issues); id. at 143-44 (defending interpretation based on the "original understanding" of constitutional language because of its fit with the constitutional text); ELY, supra note 1, at 87-101 (arguing that his "representation-reinforcement" theory fits the constitutional text uniquely well).

3. See, e.g., 1 ACKerman, supra note 1, at 22; id. at 34 (referring to the Constitution as an “evolving" historical practice); DworkIN, FreEdom's LAw, supra note 1, at 10; DwoRKIN, LAw's EMPIRE, supra note 1, at 254-58, 397-99.

4. See EPSTEIN, supra note 1, at 304-05 (arguing for a "natural law account of property that is able to resist legislative nullification").

5. See RICHARDS, supra note 1 , at $12,57-58,61-62$.

6. See Posner, supra note 1, at 7-8 (drawing a similar distinction).

7. See, e.g., Bork, supra note 1, at 144-55; ANTONIN SCALIA, A MATTER OF INTERPRETATION 38-47 (Amy Gutmann ed., 1997). 
Second, there is a surprising degree of implicit agreement among constitutional theorists about the criteria that a sound constitutional theory ought to satisfy. Part II shows that theorists both widely and correctly recognize that the choice among theories should be based on which theory will best advance shared, though vague and sometimes competing, goals of: (i) satisfying the requirements of the rule of law, (ii) preservimg fair opportumity for majority rule under a scheme of political democracy, and (iii) promoting substantive justice by protecting a morally and politically acceptable set of individual rights.

Third, theories should be judged by their likely fruits. To determine which theory would best promote ultimate goals, it is crucial to assess what kinds of judicial decisions would likely be made if a particular theory were adopted. If this conclusion is accepted, the attraction of substantive theories becomes clear, but the allure of formal theories grows puzzling. Why have so many formal theories achieved prominence? Is preference for a formal over a substantive theory inherently misguided? In Part III, I argue that the anticipated pattern of decisions depends not only on a theory's exphicit tenets, but also on who our judges and Justices are likely to be, and what values and perspectives they will bring to their decision making. A constitutional theory should be chosen with this consideration in mind.

Fourth, as is argued im Part IV, questions of constitutional theory are not optional; they cannot be put off as merely academic pre-occupations, which have no necessary role in the work of judges and lawyers. Every constitutional argument reflects methodological assumptions. A judge who relies on identifiable assumptions in one case is properly subject to criticism if her arguments in another case reflect different, inconsistent assumptions.

Of these four claims, I expect the third to engender the greatest controversy. To some, the suggestion that a constitutional theory should be selected based on its likely results may seem to invite unprincipled, resultoriented decision making that is inconsistent with obligations of constitutional fidelity and the rule of law. In Parts IV and V, however, I reject this conclusion. It would be naive and misguided to choose a constitutional theory without regard to whether it would be likely, on balance, to yield "good" results. Nonetheless, a theory, once chosen, ought to bimd any primcipled adherent to at least some results that she would otherwise reject. Agamst the background of these broader claims, Part V briefly explores the questions of who should choose a constitutional theory-imdividual judges and citizens, or the people collectively - and of the time horizon for which a theory should be adopted. 
I

\section{The Inherently VAlue-Laden Choice Between TeXT-BAsed AND Practice-Based TheORIES}

The daunting array of constitutional theories presents an immediate question: which theory is best? Yet this question may itself raise the second-order question: by what criteria should constitutional theories be assessed?

Many, if not most, constitutional theorists acknowledge that the choice among constitutional theories must be made partly on grounds external to the written Constitution. ${ }^{8}$ But proponents of text-based theories sometimes suggest that their theories are justified by their uniquely excellent fit with the written Constitution and that normative argument is therefore unnecessary. ${ }^{9}$ This position is untenable. The choice of a constitutional theory requires appeal to normative criteria, which must themselves be specified and defended.

\section{A. The Nature of Constitutional Theories}

Like legal theories generally, constitutional theories resist classification according to the division between positive or descriptive theories on the one hand and normative or prescriptive theories on the other. ${ }^{10} \mathrm{Few}$, if any, constitutional theories are purely normative. ${ }^{11}$ Most, if not all, claim to fit or explain what they characterize as the most fundamental features of the constitutional order. ${ }^{12}$ But few constitutional theories are purely

8. See, e.g., Cass R. Sunstein, Justice Scalia's Democratic Formalism, 107 YALE L.J. 529, 564 (1997) (reviewing SCALIA, supra note 7) (asserting that "any approach to interpretation must be defended partly by reference to its consequences"); Laurence H. Tribe, Comment, in ScaliA, supra note 7 , at $65,76-77$ ('In choosing among ... views of what counts as 'the Constitution,' and as binding constitutional law, one must of necessity look outside the Constitution itself.").

9. See supra note 2 and accompanying text.

10. See Richard H. Fallon, Jr., A Constructivist Coherence Theory of Constitutional Interpretation, 100 HARv. L. REV. 1189, 1231 (1987). Professor Dworkin, whose account I generally follow on this point, has suggested that legal theories should be classified as "interpretive." See DwORKIN, LAw's EMPIRE, supra note 1, at 45-113. According to Dworkin, legal theorists typically begin with a tentative or "pre-interpretive" understanding of the materials that a good legal theory ought to fit, and then craft a theory that, in addition to satisfying a requirement of fit, portrays the relevant body of law in the best moral light. See id. at 65-68. In the effort to develop a theory that shows legal practice as reflecting a body of norms that are morally deserving of extension into the future, some norms or decisions that were provisionally accepted ultimately may be rejected as mistakes or aberrations that cannot be adequately explained within a theory or body of law that is both morally attractive and internally self-consistent. See RONALD DWORKIN, TAKING RIGHTS SERIOUSLY 118-23 (1977) [hereinafter DwORKIN, TAKING RIGHTS SERIOUSLY] (discussing the need for a legal theory to include a "theory of mistakes").

11. Indeed, the response to a "purely normative" theory-for example, a theory that judges should always do whatever will have the greatest tendency to maximize utility, regardless of whether the constitutional provisions being interpreted can fairly be understood as reflecting this aim-might be that this is not a "constitutional theory" at all, but rather is a moral or political theory.

12. See Fallon, supra note 10 , at 1233 . 
descriptive either. ${ }^{13}$ Most theorists also seek to influence practice, typically by offering prescriptions for reform. ${ }^{14}$ These prescriptions aim to bring constitutional practice more fully into accord with what the various theories identify as the deepest fundamental values of the written Constitution or of surroundimg practices. ${ }^{15}$

In light of the nature of constitutional theories, an immediate question is what a good constitutional theory ought to fit or describe. Interestingly, constitutional theorists disagree about this question. Although the lines of division are complex, a rough but useful distinction exists between textbased and practice-based approaches. ${ }^{16}$

\section{Text-Based Theories}

Theories that are predominantly text-based rest their claim to acceptance on their fit with, or their capacity to explain, the written Constitution. A clear example is originalism, which calls for the Constitution to be interpreted in accordance with the "original understanding" of those who wrote and ratified relevant language and the generation to which the Constitution was originally addressed. ${ }^{17}$ Prominent originalists maintain that we can infer the appropriateness of imterpretation in accord with the original understanding from the Constitution itself. According to originalists, the Constitution plainly sets out to establisli law that binds courts as well as other governmental officials. ${ }^{18}$ In the view of originalists, law requires both

13. See id. At least one commentator has read the constitutional theory advanced by BoBBIrT, supra note 1 , as taking an entirely "descriptive approach to constitutional jurisprudence" by offering an account of six "modalities" of constitutional argument, none of which Bobbitt portrays as requiring "justification," and which, according to Bobbitt, are capable of rendering constitutional arguments "legitimate" or "true." Dennis PatTERson, LAw AND TRUTH 142 (1996). But if Bobbitt's theory were wholly "descriptive" in this way, it would offer no answer to the question, which can intelligibly arise within constitutional argument, why any decision reached within the modalities, even in cases of modal conflict, should be regarded as justifying the exercise or non-exercise of coercive power by the state. Cf. id. at 169-79 (acknowledging that modal choice invites demands for justification).

14. See Posner, supra note 1 , at 10 ("Constitutional theorists want to influence constitutional practice.").

15. See Fallon, supra note 10, at 1233-37.

16. For further explanation and qualification of this distinction, see infra notes 17-44 and accompanying text. In imtroducing the distinction between text-based and practice-based theories, I do not inean to imply that this is necessarily the most fundamental lime of division among constitutional theories, or that the theories on either side of the line all share a common purpose or motivation. My principal aim is simply to establish that anyone who is interested in constitutional law confronts threshold questions about what a good constitutional theory ought to flt, and why.

17. See, e.g., BoRK, supra note 1, at 144-55; SCALIA, supra note 7, at 38-47.

Although originalism is a clear example of a text-based theory, not all text-based theories are originalist. For example, some theorists believe that constitutional interpretation should reflect the contemporary meaning, rather than the originally understood ineaming, of some or all constitutional language. See, e.g., Tribe, supra note 8, at 65, 66-68. See generally Paul Brest, The Misconceived Quest for the Original Understanding, 60 B.U. L. REv. 204, 209-17 (1980) (differentiating textualist from original intentionalist approaches to constitutional interpretation).

18. See, e.g., BoRK, supra note 1, at 1-5; SCALIA, supra note 7, at 40-41. 
public notice and fixity of meaning. ${ }^{19}$ And the only possible source of historically fixed public meaning is the original understanding-that is, what the Constitution meant to the generation to which it was originally addressed by those who wrote and ratified it. ${ }^{20}$

Although different from originalisin in some respects, John Ely's "representation reinforceinent" theory is similarly text-focused. ${ }^{21}$ According to Ely, some provisions of the Constitution could be read in isolation as directing judges to identify rights by referring to values not enumerated in the text itself..$^{22}$ Ely also believes that the original understanding of some provisions would license judges to recognize rights not specified within the Constitution's four corners. ${ }^{23}$ Nonetheless, Ely argues that the theory that best fits the Constitution as a whole requires judges to interpret otherwise "open-ended"24 guarantees consistently with the predominant, textuallyexpressed values of procedural fairness and, especially, representative democracy. ${ }^{25}$

\section{Practice-Based Theories}

In contrast with text-based approaches, other constitutional theories are predominantly practice-based. For practice-based theories, the foundation of the constitutional order inheres in the facts of social practice. ${ }^{26}$ Proceeding from this assumption, practice-based theorists look to see what is treated in practice as the Constitution or as possessing the status of constitutional law.

Exaniples of practice-based approaches appear in the otherwise diverse writings of Ronald Dworkin, ${ }^{27}$ Bruce Ackerman, ${ }^{28}$ and David

19. See BORK, supra note 1, at 143-44; see also SCALIA, supra note 7, at 40 (asserting that the "whole purpose" of the Constitution "is to prevent change").

20. See BORK, supra note 1 , at 5 (stating that for a judge to be "bound by law" means to be "bound by the only thing that can be called law, the principles of the text ... as generally understood at the enactment").

21. See ELY, supra note 1, at 87-101.

22. See id. at 11-32.

23. See id. at 28-30 (Privileges or Immunities Clause); id. at 38 (Ninth Amendment).

24. Id. at 14 .

25. See id. at 73-104, 116-79.

26. See generally Frederick Schauer, Amending the Presuppositions of a Constitution, in Responding to Imperfection: The Theory and Practice of Constitutional Amendment 145 (Sanford Levinson ed., 1995) (noting that constitutional debates characteristically presuppose basic patterns of social practice, including practices of accepting certain texts and institutions as authoritative).

27. See, e.g., DWORKIN, Freedom's LAW, supra note 1; DWORKIN, LAW's EMPIRE, supra note 1.

28. See, e.g., 1 ACKERMAN, supra note 1; 2 ACKERMAN, supra note 1; Bruce Ackerman, Constitutional Politics/Constitutional Law, 99 YALE L.J. 453 (1989) [hereinafter Ackerman, Constitutional Politics]; Bruce Ackerman, The Storrs Lectures: Discovering the Constitution, 93 YALE L.J. 1013 (1984) [heremafter Ackerman, Storrs Lectures]. 
Strauss. ${ }^{29}$ In a striking analogy, Dworkin compares constitutional adjudication with the authorship of a "chain novel." wrote the first chapter, but Dworkin claims that widely accepted norms of legal practice obligate contemporary adjudicators to weave a narrative that fits or explains judicial precedent, as well as the constitutional text and its original history. ${ }^{31}$ Dworkin further maintains that norms of practice call for judges to depict authoritative legal materials in the best inoral light, whatever that might be..$^{32}$ According to Dworkin, a good constitutional theory inust not only fit, but must also rationalize or justify, the central features of constitutional practice. ${ }^{33}$

Bruce Ackerman also takes constitutional practice as his starting point. ${ }^{34} \mathrm{He}$ emphasizes that the norms reflected in conteinporary adjudication frequently cannot be traced to the written Constitution alone. ${ }^{35}$ To understand existing practice, he argues, we inust acknowledge that the Constitution has been informally revised by unwritten amendments, which have achieved legitimacy through informal ratification by the People..$^{36}$ In perhaps his inost arresting example, Ackerman argues that the Constitution was informally anended by the People during the New Deal era to reject limits on governmental power previously enforced by the Supreme Court. ${ }^{37}$ As a result of this amendment, he maintains, the Constitution today licenses vast federal power under the Commerce Clause, and it no longer

29. See Strauss, supra note 1.

30. See DWORKIN, LAw's EMPIRE, supra note 1, at 228-32; see also DWORKIN, FREEDOM's LAW, supra note 1, at 10 (asserting that judges "must regard themselves as partners with other officials, past and future, who together elaborate a coherent constitutional morality, and they must take care to see that what they contribute fits with the rest").

31. See DWORKIN, FREEDOM's LAW, supra note 1, at 10; DWORKIN, LAW's EMPIRE, supra note 1, at 254-59, 397-99.

32. See, e.g., DWORKIN, FreEdom's LAw, supra note 1, at 2-4; DWORKIN, LAw's EMPIRE, supra note 1 , at 355-89, 397-99.

33. See DWORKIN, LAw's EMPIRE, supra note 1, at vii, 355-89, 397-99.

34. See 1 ACKERMAN, supra note 1, at 22 (observing that "the Constitution is best understood as a historically rooted tradition of theory and practice").

35. See 2 ACKERMAN, supra note 1, at 8-31; Ackerman, Storrs Lectures, supra note 28, at 1070 72.

36. 1 ACKERMAN, supra note 1, at 44-50, 81-130; Ackerman, Constitutional Politics, supra note 28, at 499-516; Ackerman, Storrs Lectures, supra uote 28, at 1057-70; cf. 2 AcKERMAN, supra note 1, at 270 (characterizing the new constitutional understandings that resulted from the Supreme Court's "switch in time" that resulted in validation of New Deal regulatory legislation as "amendmentanalogues").

Although Ackerman differs with originalists about the content of "the Constitution" that judges should enforce, his theory is otherwise analogous to originalisin: he too believes that the proper judicial function is to identify, synthesize, and implement norms ratified by "the People" on identifiable historical occasions. See 1 ACKERMAN, supra note 1, at 89, 140-42; cf. Michelinan, supra note 1, at 1522 (noting the similarity between Ackerman's views and those of Robert Bork).

37. See 1 ACKeRMAN, supra note 1, at 47-50, 101-30; 2 ACKERMAN, supra note 1, at 279-382; Ackerman, Constitutional Politics, supra note 28, at 513-15; Ackerman, Storrs Lectures, supra note 28 , at 1057-70. 
includes the same protections of property and other economic rights that it previously did. ${ }^{38}$

As a final example, David Strauss launches his arguments for a "common law" approach to constitutional interpretation by noting that judges more frequently decide cases by reasoning from precedent than they do by appealing to the constitutional text. ${ }^{39}$ According to Strauss, constitutional law has developed-and should continue to develop-on the model of the common law, which permits desirable adaptation in light of evolving needs and values. ${ }^{40}$

\section{Blurring the Distinction}

Although clear cases of text-based and practiced-based theories are easily distinguishable, I do not mean to claim that all theories fall on one or the other side of a categorical divide. Text-based theorists cannot divorce themselves entirely from considerations of practice, and practice-based theorists recognize the importance of the written Constitution.

Text-based theories must acknowledge the significance of several social practices. For the constitutional text to be intelligible at all, it must be situated within a linguistic practice; and for the Constitution to be law, it must exist within political and legal practices that accord it that status. ${ }^{41}$ Nonetheless, in identifying the Constitution's "meaning," text-based theorists try to abstract as far away as possible from existing, specialized interpretive practices among lawyers and judges. Instead, such thcorists appeal to intuitions about how the constitutional text would be understood among a community of contemporary English-speakers who knew the Constitution's general purposes (as revealed by historical studies) and originally understood meaning, but had not been initiated into specialized practices of constitutional interpretation. ${ }^{42}$

Similarly, even the most paradiginatically practice-based theory must acknowledge that American constitutional practice has a text at its center. ${ }^{43}$ The question is never whether practice dictates a result other than that called for by the constitutional text; rather, the question is always how the

38. See 1 ACKERMAN, supra note 1, at 102-03; 2 ACKERMAN, supra note 1, at 333-82; Ackerman, Storrs Lectures, supra note 28, at 1071.

39. See Strauss, supra note 1 , at 883 .

40. See id. at 885 ("[Olur written constitution has ... become part of an evolutionary common law system, and the common law ... provides the best way to understand the practices of American constitutional law."); $i d$. at 888 . For an earlier theoretical effort to assimilate constitutional adjudication to common law adjudication, see Harry H. Wellington, Common Law Rules and Constitutional Double Standards: Some Notes on Adjudication, 83 YALE L.J. 221 (1973).

41. See Schauer, supra note 26 , at $150-57$.

42. See Scalia, supra note 7, at 37-41.

43. See, e.g., DwORKIN, FrEEdom's LAw, supra note 1, at 76-81 (arguing that all rccognized rights trace to interpretation of the written Constitution); Strauss, supra note 1, at 906-11 (noting the authority accorded to the constitutional text). 
Constitution should be interpreted or applied in light of precedent or moral or prudential considerations, as well as certain norms of practice. ${ }^{44}$

In view of these complexities, the notions of text-based and practicebased approaches may not define polar opposites so much as regions along a continuum. Nonetheless, in addition to marking an important difference of einphasis among constitutional theories, the distinction calls attention to a striking feature of contemporary debates: at least on the surface, there is disagreement concerming the appropriate subject matter of constitutional theory. Although everyone agrees that a good theory must fit or explain the central features of our constitutional order, there is disagreement about what, exactly, the most relevant features are.

\section{B. The Limits of Positivism}

Choosing between a text-based and a practice-based approach to constitutional theory requires a judgment of normative preferability. Any effort to justify a text-based approach by appeal to the written Constitution would be circular: the Constitution cannot prove the validity of a textbased approach when precisely what is at issue is whether the written Constitution is the sole source of legitimate authority in constitutional law. ${ }^{45}$ Nor, as discussed below, could practice-based theorists persuasively appeal to accepted facts of practice to justify their approach. In the face of divergent claims about what a good constitutional theory most centrally ought to fit, an important and possibly decisive consideration is whether a text-based or a practice-based approach would produce better constitutional law (as measured by appropriate standards).

Defenders of text-based approaches-especially originalistssoinetimes resist this argument. The necessary correctness of a text-based theory, they sometimes suggest, does not depend on a philosophical argument about what the law ought to be, but on an almost self-evidently valid legal argument about what the law is: everyone knows that the written Constitution is the supreme law of the Umited States, binding on courts as well as other officials. ${ }^{46}$ And if the written Constitution is the supreme law, a theory about what the supreme law is-which is to say, a constitutional theory-must necessarily fit the written Constitution. There is no need, the argument continues, to get into the question of whether it is desirable for the written Constitution to be treated as the supreme authority; it is enough

44. See DWORKIN, FREEDOM's LAw, supra note 1, at 76-81 (denying that there is a meaningful distinction between "enumerated" and "unenumerated" constitutional rights, since all recognized rights emerge from interpretation of the Constitution).

45. See Henry Paul Monaghan, Stare Decisis and Constitutional Adjudication, 88 Colum. L. REV. 723, 771 (1988); Tribe, supra note 8, at 76.

46. See BoRK, supra note 1, at 173-74; Henry P. Monaghan, Our Perfect Constitution, 56 N.Y.U. L. Rev. 353, 383-84 (1981). 
to establish that the Constitution, rather than possibly competing norms derived from legal "practice," is the ultimate law. ${ }^{47}$

However plausible it may appear on the surface, this argument begs the central questions in issue. One set of questions, emphasized by Bruce Ackerman's practice-based theory, ${ }^{48}$ mvolves what "the Constitution" is. Is the Constitution only the written document preserved in the National Archives, or does it mclude unwritten amendments? ${ }^{49}$ Is entrenched precedent now part of the Constitution im some meaningful sense ${ }^{50}$ Are widely shared and enduring values and assumptions-what the Supreme Court has referred to as the "postulates" that lie behind constitutional terms and "limit and control" their application ${ }^{51}$ — themselves of constitutional status? Another set of questions involves how to interpret "the Constitution." To acknowledge that the Constitution is the supreme law is not necessarily to accept that the best theory of constitutional interpretation will be based solely on the Constitution's text, heedless both of the way that courts have interpreted the Constitution over time and of the considerations that have given rise to a complex interpretive practice. To determine what needs to be interpreted is one thing; to identify applicable norms of interpretation may be another.

In maintaining that the written Constitution simply is the ultimate law and that any methodology of constitutional interpretation must therefore fit or derive from it alone-with no need for normative argument ${ }^{52}$ originalists attempt to cast themselves as legal "positivists" who insist on a separation between legal argument and moral argument. ${ }^{53}$ They assume that because the Constitution owes its status as ultimate law to its origins in the commands of a sovereign lawgiver, the People, ${ }^{54}$ no other norms,

47. See BORK, supra note 1, at 173-74; Monaghan, supra note 46 , at 383-84. Professor Monaghan has subsequently changed his mind. See Monaghan, supra note 45, at 771 (noting that "the relation between text and judicial gloss cannot be taken as obvious" and that the "reality" is that "[jludges and lawyers ... are centrally concerned with judicial decisions, not with the text").

48. See supra text accompanying notes 34-38.

49. Cf. Sanford Levinson, Accounting for Constitutional Change (Or, How Many Times Has the United States Constitution Been Amended? $(A)<26 ;(B) 26 ;(C)>26 ;(D)$ All of the Above), 8 ConsT. COMMENTARY 409 (1991) (noting the plausibility of recognizing unwritten amendinents); Strauss, supra note 1, at 884 (asserting "the prevalence and importance of nontextual amendments").

50. See DWORKIN, LAW's EMPIRE, supra note 1, at 398 (endorsing the view that "the American Constitution consists in the best available interpretation of American constitutional text and practice as a whole"); Thomas C. Grey, Do We Have an Unwritten Constitution?, 27 Stan. L. Rev. 703 (1975) (arguing that precedent, practice, and conventional morality effectively constitute an unwritten constitution).

51. Monaco v. Mississippi, 292 U.S. 313, 322 (1934).

52. See, e.g., BoRK, supra note 1 , at 173-74.

53. See Strauss, supra note 1 , at 886 (noting positivist pretensions of originalist theories).

54. See id. (noting that originalists treat "the Framers of the Constitution (or its ratifiers)" as functioning in the role of "Austin's sovereign" under a "command model" of the nature of law); $c f$. Lessig, supra note 1, at 1254 (explicating constitutional interpretation in terms of obligations owed by an agent to a principal). 
including interpretive norms, can attain the status of ultimate law unless they, too, trace to the saine source of sovereign authority.

Although this chain of reasoning might draw support from an older brand of legal positivism that equated law with the "command" of a sovereign (such as the Frainers or ratifiers), ${ }^{55}$ this equation is untenable. As modern positivists such as H.L.A. Hart have argued, the foundations of law (including constitutional law) do not lie in sovereign commands, but rather in social practices involving the acceptance of authority. ${ }^{56}$ Though perhaps obscured in stable legal systems, the crucial role of acceptance becomes mamifest in cases of what we call "revolution." The commands of Parliament did not cease to be law in the Umited States because Parliannent commanded that its decrees should no longer be law here; British enactments ceased to be law because they ceased to be accepted as such in the former American colonies.

Seen against the background of this more enlightening framework, the legal status of the Constitution does not depend on the "command" of the Framers or ratifiers that we, the people of today, act in accordance with the Constitution's dictates. Nor are interpretive practices necessarily illegitimate if they are not similarly traceable to the commands of an identifiable sovereign. Rather, the status of the Constitution as law depends on contemporary practices accepting it as such..$^{58}$

If the Constitution's status as ultimate law depends on practices of acceptance, then the claim that the written Constitution is the only valid source of constitutional norms loses all pretense of self-evident validity. ${ }^{59}$ As originalists candidly admit, originalist principles cannot explaim or justify much of contemporary constitutional law..$^{60}$ Important lines of

55. The classic "positivist" text attempting to associate the concept of law to the commands of a sovereign lawgiver is John Austin, The Province of Jurisprudence Determined, in The Province of JURISPRUDENCE DETERMINED AND THE USES OF THE STUDY OF JURISPRUDENCE 1 (H.L.A. Hart ed., Noonday 1954). See generally Anthony J. Sebok, Misunderstanding Positivism, 93 Mrch. L. Rev. 2054, 2064-65 (1995) (identifying the "command theory of law" as a constitutive principle of "classical" legal positivism). For the classic critique of the command theory and an effort to reestablisl legal positivism on more tenable foundations, see H.L.A. HART, THE CONCEPT OF LAW 18-99 (1961).

56. Hart suggested that the relevant social practices could be captured in a "rule" or rules "of recognition." See HART, supra note 55, at 97-120, 245-47. This formulation was probably misleadimg. See Schauer, supra note 26 , at 150 ("There is no reason to suppose that the ultimate source of law need be anything that looks at all like a rule ... or even a collection of rules, and it may be less distracting to think of the ultimate souree of recognition ... as a practice."). But Hart's deep point does not depend on whether relevant social attitudes and practices can be described in rule-like form. Even if the sovereign's commands are the law, they are not the law because the sovereign has commanded that the sovereign's commands should be law, but because relevant parts of the population accept the sovereign's commands as authoritative.

57. See HART, supra note 55, at 114-16 (discussing revolutions).

58. See Schauer, supra note 26 , at 50-57.

59. See Monaghan, supra note 45 , at 771 .

60. See, e.g., BERGER, supra note 1, at 69-282; BoRK, supra note 1, at 19-128. 
precedent diverge from original understandings. ${ }^{61}$ Judges frequently take other considerations into account. ${ }^{62}$ Moreover, the public generally accepts the courts' non-origmalist pronouncements as legitimate ${ }^{63}$ - not merely as fimal, but as properly rendered. ${ }^{64}$

In urging that existing judicial practices should be altered, originalists are not pure positivists, who msist that the "rule of recognition" prevailing in the United States reflects originalist principles. ${ }^{65}$ Rather, originalists, like all other participants in constitutional theoretical debates, carry a burden of normative justification. They must attempt to establish that the constitutional regime would be a better one-as ineasured by relevant criteria-if constitutional practice were exclusively text-based and if originalist precepts were consistently followed. Indeed, as I shall argue below, many originalists inplicitly acknowledge as much: like proponents of other theories, originalists commonly appeal to values associated with the rule of law, political democracy, and individual rights in defending their interpretive methodology. ${ }^{66}$

If text-based theorists inust ultimately offer normative arguments for reform, it might appear that practice-based theorists could assume the positivist mantle. They could then assert that their position fairly expresses what the law simply is, ${ }^{67}$ and claim that $m$ light of the "lawfulness" of their

61. See, e.g., BoRK, supra note 1, at 19-128; Monaghan, supra note 45, at 727-39.

62. See DwORKIN, FREEDOM's LAw, supra note 1, at 3 ("Lawyers and judges, in their day-to-day work, instinctively treat the Constitution as expressing abstract moral requirements that can only be applied to concrete cases through fresh moral judgments ...."); SCAL1A, supra note 7, at 38-49 (acknowledging that in the dominant approach to constitutional interpretation, judges take into account considerations other than the original understanding); Monaghan, supra note 45, at 771-72.

63. See Charles L. Black, JR., The People and the Court 209 (1960) (arguing that the continued acceptance of judicial review as practiced by the courts could not have occurred in the facc of perceived illegitimacy).

64. Cf. HART, supra note 55, at 141-42 (distinguishing between the finality and the correctness of decisions by an ultimate tribunal).

65. John Ely similarly acknowledges that much of our constitutional practice-which is to say much of the constitutional law of the United States (in the rule-of-recognition sense)-flatly rejects the strictures on constitutional interpretation that he endorses. See John Hart Ely, Another Such Victory: Constitutional Theory and Practice in a World Where Courts Are No Different from Legislatures, 77 VA. L. REv. 833 (1991). He, too, presses a call for reform that is based on an interpretation of the constitutional text, and not on a social-fact-based account of what the positive law is.

66. See infra notes 76-88 and accompanying text.

67. Cf. 2 ACKERMAN, supra note 1, at 92 (characterizing his theory as a species of "humanistic positivism"). Any effort to classify text-based and practice-based theorists as positivists and nonpositivists abounds with surface ironies. If "positivism" equates law with what is accepted as law as a matter of social fact, see supra notes 55-56 and accompanying text, practice-based theorists look more like positivists than do originalists, whose positions some deride as positivist, or even "authoritarian." See, e.g., Michelman, supra note 1, at 1522; Robin L. West, The Authoritarian Impulse in Constitutional Law, 42 U. Miam L. REv. 531, 534-35 (1988) (associating efforts to find answers to constitutional questions in historical material with "the 'authoritarian tradition""). Yet because practicebased theorists often call for judges to make important and contestable moral decisions, they are themselves frequently derided by originalists for failing to respect the positivist distinction between law 
approach, they need offer no further normative justification. But this route is not open to practice-based theorists. Norms of practice foreclose it. Amid widespread methodological contention, ${ }^{68}$ it is the conventionally accepted function of constitutional theory not merely to prescribe an approach, but to justify it by reference to shared norms or values. ${ }^{69}$

In short, neither text-based nor practice-based theorists can stand outside of morally charged debates about the comparative desirability of competing constitutional theories. One must choose a constitutional theory at least partly on extra-textual grounds. Indeed, among the central challenges in choosing a constitutional theory is to determine which text or texts to work with-that is, whether to prefer a text-based or a practice-based approach.

II

\section{Three Shared Evaluative Criteria}

In defending their preferred methodological approaches, constitutional theorists necessarily appeal to evaluative criteria. As I have suggested already, it appears to be agreed all around-indeed, accepted as nearly defimitional of the enterprise of constitutional theorizing - that one important criterion is "fit." A good constitutional theory must fit either the written Constitution or surrounding practice. In the absence of a fit requirement, constitutional theory would lose its anchor in law and collapse into political theory. As discussed in Part I, however, arguments about whether constitutional theories satisfy the fit criterion often appear not to engage one another, due to disagreement about whether it is the written Constitution or constitutional practice that a theory most importantly ought to reflect.

It does not follow, however, that there are no widely accepted standards by which different kinds of constitutional theories can be tested and compared. In adopting either a text-based or a practice-based approach, and then in embracing more specific methodological prescriptions, constitutional theorists typically appeal to three shared criteria. Almost without exception, theorists claim that their preferred approaches optimally realize sometimes competing values associated with (i) upholding the rule of law,

and morals. See, e.g., BoRk, supra note 1, at 1-5, 251-53. Much of the confusion, and the surface irony, undoubtedly results from a failure to distinguish a number of analytically variant positions that are sometimes grouped together under the "positivist" label. For some valuable clarifications, see Jules L. Coleman, Negative and Positive Positivism, 11 J. Legal Stud. 139 (1982).

68. See, e.g., DWORKIN, LAw's EMPIRE, supra note 1, at 13 (characterizing legal practice as "argumentative"); Fallon, supra note 10, at 1234-37 (discussing disagreement about "rules" of constitutional practice and their proper application).

69. See David A. Strauss, What Is Constitutional Theory?, 87 CALIF. L. REv. 581, 582 (1999). 
(ii) promoting political democracy, and (iii) advancing substantive justice by respecting a inorally defensible set of individual rights. ${ }^{70}$

As is evident on the surface, these criteria are extremely vague. Although nearly everyone agrees that the rule of law, democracy, and individual rights are important values, there is rampant disagreement about how these concepts are best understood. For example, some people believe that the rule of law requires clear rules; ${ }^{71}$ others endorse a conception of the rule of law that is entirely consistent with common-law decision making. ${ }^{72}$ There are similar disagreements about what democracy is or requireswhether, for example, democracy entails that popular inajorities should be able to achieve any result that they wish, or whether a position is properly "democratic" only if it reflects respect for the equal worth of every citizen. ${ }^{73}$ It is also notorious that different conceptions of justice generate different views of the rights, if any, that people have..$^{74}$

In saying that competing constitutional theorists appeal to common values, I therefore do not inean to suggest that they agree about how those values are best understood. Because deep agreement is lacking, neither do I mean to suggest that disputes about constitutional theory should be easily resolvable once the terms of debate are clarified. My aim, in a sentence, is to illuuminate debates about constitutional theory, rather than to resolve them. Somewhat more precisely, I hope to explicate for the possibly puzzled observer low it is that proponents of text-based and practice-based constitutional theories (and other seemingly divergent kinds of constitutional theories, such as methodological and substantive theories) are not simply talking past each other. Proponents of constitutional theories are

70. In one sense, fit is, of course, a fourth shared criterion. As explained in the text, however, the fit requirement stands on a shightly different plane from the other three evaluative criteria because the other criteria can be and often are invoked to assess what exactly it is that a constitutional theory ought to fit.

71. See, e.g., Friedrich A. Hayek, The Political IDEal, of the Rule of LaW 32-45 (1955); Friedrich A. HayeK, The RoAd to Serfdom 72-87 (1944); Antonin Scalia, The Rule of Law as a Law of Rules, 56 U. CHr. L. Rev. 1175 (1989).

72. See Richard H. Fallon, Jr., "The Rule of Law" as a Concept in Constitutional Discourse, 97 CoLUM. L. REV. 1, 18-21 (1997) (discussing the work of authors who implicitly or explicitly assume a "legal process" ideal type of the rule of law).

73. See DWORKIN, FReEdoM's LAW, supra note 1, at 15-26.

74. Among modern works, the most celebrated theory is undoubtedly that of John Rawls. See JOHN RAWLS, A THEORY OF JUSTICE (1971). Rawls's theory provides that "each person is to have an equal right to the most extensive basic liberty compatible with a similar liberty for others," and further provides that social and economic imequalities are permissible only insofar as they are "(a) reasonably expected to be to everyone's advantage, and (b) attacbed to positions and offices open to all." Id. at 60 . Among Rawls's most prominent critics, Robert Nozick argues in favor of a much more libertarian approach, which recognizes a quite different set of rights, largely designed to protect individual citizens and the fruits of private initiative from governmental regulation. See RoBERT NozICK, ANARCHY, STATE, AND UTOPIA at ix (1974). Michael Sandel broadly challenges the notion that public policy and private inorality should be organized by liberal conceptions, including the concept of "rights" as defined by both Rawls and Nozick. See Michael J. SaNDEL, Liberalism aNd THE Limits of Justice (1982). 
participants in a single intelligible debate, even if the debate is deep and multi-faceted.

By showing how disagreements in constitutional theory are specifically bound up with diverging positions about the rule of law, democracy, and individual rights, I also hope to provide a framework within which readers can determine how various constitutional theories should be assessed in light of their own views about the rule of law, political democracy, and the individual rights necessary for substantive justice. But I do not attempt in this Article to advance substantive arguments about the best understanding of the rule of law, political democracy, or mdividual rights, nor do I advance a constitutional theory of my own.

I also should clarify that, in identifying three commonly accepted evaluative criteria for constitutional theories, I do not mean to offer transcendent or foundational arguments. Questions about appropriate evaluative criteria for constitutional theories arise within the same debates in which those criteria are imvoked.$^{75}$ In principle, such questions are therefore as contestable as any others. In the face of possible contest, my central claim is empirically grounded: within contemporary debates, the ultimate disagreement is not about whether constitutional theories should be tested by three basic criteria, but about how these criteria-when identified at a sufficiently high level of generality-are best interpreted, applied, and weighed agamst each other.

Although I advance a broad claim that debates about constitutional theory typically assume the applicability of three specific criteria, my efforts at documentation are necessarily limited. I shall try to suggest the plausibility of my assertion, however, by arguing that selected well-known theorists at least implicitly mvoke the three criteria listed above in defendmg their theories. Among text-based theorists, I take my illustrations from the writings of the originalists Robert Bork and Antonin Scalia and the "representation-reinforcement" theorist John Ely. For representatives of the practice-based approach, I discuss the theories advanced by Ronald Dworkin, Bruce Ackerınan, and David Strauss.

\section{A. Text-Based Theories}

In defending their theories agaimst rivals, text-based theorists typically rely perhaps most heavily on an ideal of the rule of law. Both Judge Bork and Justice Scalia, for example, maintain that only an originalist methodology can ensure the fixity of legal meaning, the predictability of results, and

75. See Robert Post, Theories of Constitutional Interpretation, 30 RePResentations 13, 27 (1990) (denying that there could be forms or sources of constitutional authority external to the practice of constitutional interpretation). 
the constraint on judges that the rule of law (in their view) requires. ${ }^{76}$ Each suggests that it is incompatible with the rule of law for judges to decide cases based on their own moral views-as each contends that judges will inevitably do unless they are bound by historically understood ineanings. ${ }^{77}$

Sophisticated originalists such as Bork and Scalia do not, however, rest solely on the rule of law. For one thing, the rule of law admits competing conceptions or interpretations, ${ }^{78}$ and realization of rule-of-law values is not an all-or-nothing proposition. ${ }^{79}$ As proponents of more common-lawlike approaches emphasize, common law regimes are often held up as paradigms of the rule of law, at least outside the possibly peculiar context of constitutional law..$^{80}$

In response to such arguments, Bork and Scalia, like other proponents of text-based approaches, appeal to the second evaluative criterion, involving political democracy. They argue that political majorities should be able to determine public policy without being frustrated by judicial decisions that reflect the judges' moral values. ${ }^{81}$ Constitutional law differs from the common law, the argument continues, because democratically accountable legislatures cannot reject constitutional decisions in the sane way that they can reject common law judgments. ${ }^{82}$

Although the argument from political democracy may cut against certain constitutional theories, it fails to establish the umique correctness of originalism. Among other things, originalist theory itself prescribes that judges should invalidate at least some legislation that is supported by political majorities-namely, legislation that is incompatible with the original understanding. The question thus arises: in what sense is democracy advanced when decisions are ruled by the understandings of people who have long since died? At the very least, shouldn't judges indulge every reasonable presumption in favor of upholding statutes that are supported by contemporary majorities? ? $^{33}$

76. See Bork, supra note 1, at 1-5, 143-46, 154-55; Antonin Scalia, Originalism: The Lesser Evil, 57 U. Cin. L. Rev. 849, 854, 862-63 (1989).

77. See BORK, supra note 1, at 1-5; Scalia, supra note 76 , at 863 .

78. See Fallon, supra note 72, at 10-24 (sketching four competing conceptions of the rule of law).

79. See id. at 7.

80. See id. at 51 .

81. See United States v. Virginia, 518 U.S. 515, 567 (1996) (Scalia, J., dissenting) (criticizing the Supreme Court najority for "inscribing" current preferences into the Constitution and arguing that the Constitution, as originally understood, embodied "[t]he virtue of a democratic system" that "enables the people, over time, to be persuaded that what they took for granted is not so, and to change their laws accordingly"); Planned Parenthood v. Casey, 505 U.S. 833, 1001 (1992) (Scalia, J., dissenting) (arguing that value judgments not made by the Constitution "should be voted on, not dictated" by courts); BoRK, supra note 1, at 139-41, 264, 351-52.

82. See BoRk, supra note 1, at 6-7; ScAliA, supra note 7, at 38.

83. See James Bradley Thayer, The Origin and Scope of the American Doctrine of Constitutional Law, 7 HARv. L. REv. 129, 144 (1893) (arguing for judicial invalidation of federal statutes only when 
In defending a non-deferential judicial role in implementing original constitutional understandings, Judge Bork emphasizes that the Constitution strikes a balance between the rights of the majority and the rights of minorities. ${ }^{84}$ This response could, of course, be understood descriptively; it simply asserts a fact about our Constitution. But Bork clearly expects the argument to have moral resonance. As between the rights of majorities and the rights of minorities, he seems to imply, the written Constitution-as measured by historical understandings-reflects at least a sound approximation of substantive justice. ${ }^{85}$ By adhering to the historically understood meaning, we get a more than acceptable mix of democratic decision makmg and protected substantive rights.

Justice Scalia appears to rely on a similar preimise when he argues that an originalist methodology-which promises firm legal rules to steel judges against the temptation to decide cases in line with prevailing sentiments-may be necessary to ensure the effective protection of substantive rights. ${ }^{86}$ Why should we care about the enforcement of the Constitution to thwart political majorities, if not because the legal rights created by the Constitution are morally deserving of protection?

Justice Scalia further suggests that constitutional theory must satisfy interests in ensuring protection of a morally and politically acceptable set of individual rights when he describes his own brand of originalisin as appropriately "faint-hearted." 87 A defensible originalisin, he argues, inust "coine to terins with [the] reality" that judges would not and apparently should not sustain practices that, although understood as constitutionally acceptable by the framing and ratifying generation, would be broadly condemned today as cruel and unusual. ${ }^{88}$

Congress has made "a very clear" mistake); $c f$. id. at 154-55 (noting that the "clear mistake" rule should not apply in cases involving federal judicial review of state legislation).

84. See BoRk, supra note 1 , at 139-41.

85. See id. at 353-55. According to Bork, "[t]he attempt to define individual liberties by abstract moral philosophy," rather than by the original understanding, "is actually likely to make [individual liberties] more vulnerable." Id. at 353. And Bork finds this prospect "terrifying," id., within the framework of a self-consciously Burkean view of the liberties that ought, in the moral sense, to be protected:

What Burke said of the abstract theorists who produced the calamities of the French Revolution might equally be said of those, judges and professors alike, who would remake our constitution out of moral philosophy: "This sort of people are so taken up with their theories about the rights of man that they have totally forgotten his nature." Those who made and endorsed our Constitution knew man's nature, and it is to their ideas, rather than to the temptations of utopia, that we must ask our judges adhere.

Id. at 355 (footnote omitted).

86. See SCALIA, supra note 7, at 41-47; Scalia, supra note 76, at 855-56.

87. Scalia, supra note 76, at 864; see also Robert Post, Justice for Scalia, 45 N.Y. REv. Books 57, 60 (June 11, 1998) (concluding that this example reveals Scalia's recognition that constitutional adjudication must respond to the "purpose" of expressing "principles that constitute the national ethos").

88. Scalia, supra note 76 , at 861 . 
John Ely's defense of his text-based "representation-reinforcement" theory depends on substantially the same criteria-although, as might be expected, im a slightly different order of priority. The heart of his argument appeals to political democracy. ${ }^{89}$ According to Ely, any acceptable theory of judicial review must accord with democratic values. He therefore argues that courts should interpret "the Constitution's open-ended provisions" ways that support, rather than contravene, political democracy. ${ }^{91}$ But Ely's argunnent also implicitly, if not explicitly, invokes the rule of law and appeals to other substantive values. He commences his defense of his theory by attacking methodologies that ask judges to identify "fundamental values." 92 Such theories, he argues, call for inherently subjective decision making that is, he may be understood to imply, inconsistent with the rule of law. ${ }^{93}$ Finally, although his express reliance on substantive values is not extensive, ${ }^{94}$ Ely acknowledges that the text of the Constitution-which he argues that his theory respects uniquely well-protects a number of substantive values that, $\mathrm{m}$ his words, make it "worth fighting for."”s

\section{B. Practice-Based Theories}

In presenting and defending their approaches, practice-based theorists characteristically invoke the same criteria as text-based theorists: the rule of law, political democracy, and the proinotion of a morally and politically acceptable set of individual rights. Though the priority accorded to these values varies from one theory to another, no one disputes that all three are relevant.

Ronald Dworkin's Law's Empire ${ }^{96}$ proceeds largely by defending a jurisprudential conception of law and, thus, of the rule of law. ${ }^{97}$ According to Dworkin, the ideal of law demands principled justification for the exercise of force by the state..$^{98}$ In light of this ideal, the rule of law requires judges to reach decisions that not only are consistent in principle with past legal authorities, but also characterize the relevant authorities in the best moral light. ${ }^{99}$ Needless to say, Dworkin's conception of the rule of law is

89. See ELY, supra note 1, at 4-9, 73-104.

90. Id. at 41 .

91. See id. at 102-03.

92. See id. at 43-72.

93. See id. (criticizing strands of reasoning that end np accepting judges' imposition of their own values in the guise of enforcing the Constitution).

94. For the argument that Ely's purportedly process-based theory pervasively reflects substantive judgments, see Paul Brest, The Substance of Process, 42 OHIo ST. L.J. 131 (1981).

95. ELY, supra note 1, at 100.

96. DwORKIN, LAw's EMPIRE, supra note 1.

97. See id. at 93 (equating the characterization of "law" offered in the book with "the rule of law").

98. See id.

99. See DWORKIN, FreEdom's LAW, supra note 1, at 37; DWORKIN, LAw's EMPIRE, supra note 1, at 225 ("According to law as integrity, propositions of law are true if they figure in or follow from the 
contestable. ${ }^{100}$ In stark contrast with the view endorsed by originalists, Dworkin's ideal requires judges to make open judgments of "political morality" 101 in determining how judicial precedent, as well the values reflected in the language and structure of the written Constitution, would "best" be characterized. ${ }^{102}$ Among the virtues of his view, Dworkin maintains, is that it can plausibly explain the extent to which American legal practice is "argumentative," 103 or rife with disagreement about what the Constitution means, without therefore being lawless.

Dworkin also presents his theory as framed to promote individual rights and as consonant with political democracy. His theory authorizes judges to define rights im morally correct terms, rather than (as originalists would msist) being bound by the conceptions that prevailed in past eras. ${ }^{104}$ Dworkin further msists that constitutional rights, once defined, should not yield easily even to important policy interests. ${ }^{105}$ Having located the affirmative grounds for preferring his theory largely in the rule of law and substantive justice, Dworkin argues that his recommendations accord with the ideal of political democracy, rightly understood. ${ }^{106}$

Bruce Ackerman's practice-based theory carries its democratic coinmitment on the surface. ${ }^{107}$ By recognizing the possibility of informal constitutional ainendments, his theory defends the prerogative of aroused majorities to revise the Constitution without going through the cumbersome procedures specified in Article V. ${ }^{108}$ Some have viewed the notion of unwritten constitutional amendments as antithetical to the rule of law, because stability and determinacy may be hard to achieve without a written text. ${ }^{109}$ Against this objection, Ackerman argues that his theory is necessary

principles of justice, fairness, and procedural due process that provide the best constructive interpretation of the community's legal practice."); $i d$. at 254-58.

100. See Fallon, supra note 72 , at 7 (noting that "the rule of law" is an "essentially contested concept").

101. Dworkin, FreEdom's LAw, supra note 1, at 2, 37.

102. See id. at 11, 37; DwORKIN, LAW's EMPIRE, supra note 1, at 355-89, 397-99.

103. DWORKIN, LAW's EMPIRE, supra note 1, at 13.

104. See DWORKIN, FreEdom's LAW, supra note 1, at 2-4; DWORKTN, LAW's EMPIRE, supra note 1 , at 364-65, 368-69.

105. See, e.g., Dworkin, TAKING Rights SERIousLy, supra note 10, at xi (defining rights as "trumps").

106. See DWORKIN, FREEDOM's LAW, supra note 1, at 15-35 (distinguishing "majoritarian" democracy from "constitutional" democracy, which insists that all persons be treated with equal concern and respect, and arguing that his theory is consistent with "constitutional," though not "majoritarian," democracy).

107. Frank Michelman has described Ackerman's theory as the "most deeply popularist ... constitutional theory now going." Michelman, supra note 1, at 1520 .

108. See 1 ACKERMAN, supra note 1, at 266-94; 2 ACKERMAN, supra note 1, at 28-31; Ackerman, Storrs Lectures, supra note 28 , at 1057-70.

109. See, e.g., BoRk, supra note 1, at 215 (describing Ackerman's theory as "an invitation for coup by judiciary"); RICHARD A. POSNER, OverCOMING LAW 228 (1995) (describing Ackerman's theory as "[d]angerous because it invites judges to treat the popular will as a form of higher law entitling them to disregard ordinary concepts of legality"); Charles Fried, The Supreme Court, 1994 
to defeat the nihilistic claim, which is rendered plausible by the departure of constitutional doctrine from original understandings of the constitutional text, that judges simply shape constitutional law to their own political values. ${ }^{110}$ Far from abandoming the rule of law, his theory may thus help to explain how the rule of law could survive in our constitutional order, in which judicial practice is impossible to explain persuasively by reference to the written Constitution alone. ${ }^{111}$

Ackerman's appeals to substantive justice sound two major themes. First, he believes that the "informal" amendments that occurred during the New Deal marked an important step toward substantive justice, both by abolishing many of the economic "rights" recognized through the Lochner ${ }^{112}$ era and by licensing a welfare state. ${ }^{113}$ Second, Ackerman accepts that the path of further moral progress must lie through an appropriately constrained and structured democratic process, such as his theory attempts to ensure. ${ }^{114}$ To be defensible, any political scheme must be reasonably democratic. Ackerman believes that what he calls "dualist democracy"115_in which a politically aroused citizenry can establish constitutional norms that subsequently bind political majorities-offers better prospects for recogmition and enforcement of a defensible set of individual rights than would a framework in which rights either could not be entrenched at all, or could be entrenched only by the cuinbersome formal process outlined in Article V.116

The final practice-based theory to which I have referred, David Strauss's "common law" theory of constitutional interpretation, emphasizes the importance of substantive justice. ${ }^{117}$ According to Strauss, judges serve this interest best by proceeding on the basis of a critical traditionalism; they should assume that prior authorities represent distilled

Term-Foreword: Revolutions?, 109 HARv. L. REv. 13, 30-33 (1995) (criticizing Ackerman's thcory by arguing that for the Constitution to funetion as law, it requires "a core of tcxtuality").

110. See Ackerman, Storrs Lectures, supra note 28, at 1070-72.

111. See 2 ACKERMAN, supra note 1, at 30 (arguing that although there are not clear "rules" governing procedures of informal constitutional amendment, controlling principles and prccedents can be identified, and that "there is more to law than rules").

112. Lochner v. New York, 198 U.S. 45 (1905).

113. See Bruce Ackerman, Rooted Cosmopolitanism, 104 ErHics 516, 524 (1994) (characterizing "the New Deal [asl a crucial constitutional breakthrough," though as one that did not "go nearly far enough"); see also Suzanna Sherry, The Ghost of Liberalism Past, 105 HARv. L. REv. 918, 933-34 (1992) (reviewing 1 ACKERMAN, supra note 1) (arguing that Ackerman's constitutional theory aims to protect New Dcal liberalisin from conservative political attacks by endowing it with a constitutional foundation).

114. See 1 ACKERMAN, supra note 1, at 318 (asserting that "lasting progress" toward social justice is inore likely under his political and constitutional theory of "dualist democracy" than under rival theories); 2 ACKERMAN, supra note 1, at 409 (embracing an idcal of "popular sovereignty"); Ackerman, supra note 113, at 535.

115. See 1 ACKERMAN, supra note 1, at 6-7.

116. See id. at 318 .

117. See Strauss, supra note 1, at 891-97. 
wisdom, ${ }^{118}$ but retain the critical capacity to modify or even reject past approaches. ${ }^{119}$ Strauss defends his theory as consistent with the rule of law; he argues that "the common law method has a centuries-long record of restraining judges." ${ }^{120} \mathrm{He}$ also addresses arguments that common-law-like constitutional decision making is anti-democratic. ${ }^{121}$ Among other things, Strauss maintains that, given the age of the written Constitution, commonlaw-like decision making may permit judges to temper what otherwise would be anti-democratic rule by the norms of past generations. ${ }^{122}$

\section{Continuing Disagreement and an Agenda for Further Analysis}

In identifying implicit agreement about three criteria (besides "fit") against which constitutional theories should be judged-involving relative capacities to promote the rule of law, democracy, and the protection of individual rights - iny argument has necessarily proceeded at a high level of abstraction. In order to choose a constitutional theory in an imformed and deliberative inanner, anyone would therefore have to proceed several steps further than I have gone. The ideals of the rule of law, democracy, and individual rights need to be elaborated more fully; judgments also need to be made about how these three desiderata should be balanced against each other.

I shall not, however, atteinpt the further, necessary analysis in this Article. My aim, so far, has been to clarify the terms of contemporary debate about constitutional theory. I would hope that partisans on all sides might agree with my claims about tacit, underlying agreement on the criteria by which competing theories should be judged. By contrast, further analysis would swiftly require me to judge the merits of large, if not intractable, disputes-for exainple, about what is the best understanding of the rule of law ${ }^{123}$ and deinocracy, ${ }^{124}$ and about which rights ought to be protected as a matter of substantive justice. I must leave this daunting challenge for another occasion. My goal in this Article is not to furnish a fully worked out constitutional theory, but to identify the paths down which anyone who would evaluate constitutional theories must be prepared to tread.

118. See id. at $891-94$.

119. See id. at 894-97.

120. Id. at 927.

121. See id. at 925 .

122. See id. at $928-34$.

123. For further arguments about how this concept would best be understood, see Fallon, supra note 72 , at $42-55$.

124. For recent discussions of competing conceptions of democracy and their relevance to constitutional adjudicatiou, see DwORKIN, FrEedoM's LAW, supra note 1, at 15-26, and Frank I. Michelman, Brennan and Democracy, 86 CALIF. L. Rev. 399 (1998). 


\section{Assessing the Prevailing Criteria}

In light of my aspiration to clarify the bases on which a constitutional theory should be selected, I must, however, confront one further question: should anyone choosing or assessing a constitutional theory accept the evaluative criteria to which leading theorists currently appeal, or should the prevailing terms of debate be rejected or modified? In iny judginent, the current criteria all deserve acceptance as centrally relevant to the assessinent of constitutional theories. It is a harder question whether the familiar criteria should be treated as exclusive. In my view, at least one further factor deserves consideration, though inore in a secondary or tiebreaking than im a primary role. This is the relative likelihood that any particular theory might earn broad acceptance as a reasonable framework for judicial decision making.

\section{The Relevance of the Prevailing Criteria}

Diverse considerations, representing a broad range of plausibly valuable perspectives, converge to support the testing of constitutional theories against mixed, weighted interests in the rule of law, political democracy, and individual rights. The rule of law is both an end in itself and an instrumental good that enables the planning, trust, and productive enterprise on which such constitutional aspirations as "the general Welfare" and "the Blessings of Liberty"125 depend. ${ }^{126}$ As a more nearly descriptive matter, both the constitutional text and constitutional practice invite characterization in light of rule-of-law values. Marbury $v$. Madison ${ }^{127}$ famously identified the Constitution with law, and rule-of-law arguments resound in contemporary constitutional discourse. ${ }^{128}$ As Lon Fuller demonstrates, a workable legal order requires adherence to rule-of-law values such as fair notice, stability, and predictability. ${ }^{129}$

As diverse theorists have recognized, political democracy expresses respect for the inoral equality of persons. ${ }^{130}$ Democracy is also a necessary (but not a sufficient) condition for realization of the satisfactions that can attend collective self-government. ${ }^{131}$ Moreover, democracy remains probably the best device to ensure government that is reasonably responsive to

125. U.S. Const. preamble.

126. See generally Fallon, supra note 72, at 7-9 (cataloguing purposes and elements of the ruleof-law ideal).

127. 5 U.S. (1 Cranch) 137,163 (1803).

128. See Fallon, supra note 72, at 24-36.

129. See, e.g., LON L. FulLer, The Morality of Law 33-94 (rev. ed. 1964) (employing the fable of King Rex to illustrate how failure to comply with rule-of-law values can result in inefficacy in producing any law at all).

130. See, e.g., DWorkIN, FreEdom's Law, supra note 1, at 15-35; Michelman, supra note 1.

131. Cf. Michelman, supra note 1 (considering necessary conditions for citizens to be both selfgoverning and ruled by law). 
the will of the people. ${ }^{132}$ Like the rule of law, the value of political democracy is also firmly rooted both in the text of the written Constitution ${ }^{133}$ and in surrounding practices and traditions. ${ }^{134}$

Finally, guaranteeing individual rights is a central requirement of substantive justice, which should be the ultimate end-or, as Rawls has said, "the first virtue" - of all legal systeins. ${ }^{135}$ Within the western legal and philosophical traditions, there tends to be less debate about whether rights should be protected than about exactly which rights ought to be recognized. ${ }^{136}$ It goes virtually without saying that a commitment to respecting individual rights is a hallmark of the American Constitution and surrounding legal practice.

\section{Other Criteria}

In defending the status of the rule of law, deinocracy, and an acceptable set of individual rights as criteria against which constitutional theories should be measured, I would not rule out the possibility that other evaluative criteria might reasonably be invoked. Among other things, affirming the contrary view would require proof of a negative: that no other consideration is ever relevant. Although not teinpted by this extravagant proposition, I would defend the weaker view that the currently prevailing frainework of debate requires no inajor reorientation at this time; the three criteria commonly appealed to in current debates are sufficiently capacious to subsume most, if not all, plausibly relevant values. Two examples may illustrate this claim. First, it is an obvious concern whether a particular theory would permit a "workable" government that can respond effectively to changing needs and exigencies. ${ }^{137}$ A second, closely related consideration is whether a theory would conduce to wealth maximization or economic

132. See Robert A. DAhL, Democracy AND ITs Critics 93-96 (1989).

133. See, e.g., ELY, supra note 1, at 87-101.

134. See id. at 5 ("We have as a society from the beginning, and now almost instinctively, accepted the notion that a representative democracy must be our form of government.").

135. RAWLS, supra note 74, at 3 ("Justice is the first virtue of social institutions.").

136. Compare RAwLs, supra note 74, at 60-108 (defending a scheme of rights that is not violated by and may indeed require the redistribution of wealth pursuant to egalitarian principles), with NozIcK, supra note 74, at 149-231 (defending a scbeme of rights against governmental redistribution as well as against private interference with liberty and property). There are, to be sure, critics of the rights-based approaches that dominate contemporary legal and philosophical debates. See, e.g., Mark Tushnet, An Essay on Rights, 62 TEx. L. REv. 1363, 1363-64 (1984) (arguing that rights are unstable and indeterminate, that they unduly reify experience, and that " $[t]$ he use of rights in contemporary discourse impedes advances by progressive social forces"); see also Frances O1son, Statutory Rape: A Feminist Critique of Rights Analysis, 63 TEx. L. REv. 387, 412 (1984) ("In general, rights analysis is merely indeterminate; it contributes nothing to the resolution of concrete cases.").

137. See Youngstown Sheet \& Tube Co. v. Sawyer, 343 U.S. 579, 635 (1952) (Jackson, J., concurring) (arguing that separation-of-powers principles should be imterpreted im light of this aim); A Workable Government? The Constitution After 200 Years (Burke Marshall ed., 1987) (exploring whether the Constitution remains workable). 
efficiency ${ }^{138}$ Although it is surely possible to imagine constitutional theory debates focused directly on these desiderata, the same concerns can be addressed, however imperfectly, under the rubrics of fit and, especially, political democracy and respect for individual rights.

Concerns of workability and economic efficiency can be at least partly subsumed under the criterion of political democracy because, in the first instance, the responsibility for developing effective governmental programs should almost always devolve on politically accountable institutions. For example, the national government may need to respond to a depression in ways never imagined by the founding generation, or a foreign policy crisis may call for an urgent response that neither the constitutional text nor accepted practice explicitly authorizes. Almost never, however, should it be the responsibility of the courts to specify a course of action. The question, in other words, is not whether the Constitution requires that something be done, but whether-in light of the concern to permit effective political democracy, among other things-the Constitution should be read to permit or to forbid action that democratic institutions would otherwise wish to take. ${ }^{139}$ As partly subsumed under the criterion of political democracy, workability and efficiency count as values in constitutional theory debates insofar as they are likely to be embraced as values by democratic majorities.

Concerns about workability and efficiency also get filtered through the evaluative criterion involving a morally and politically defensible set of imdividual rights. Questions of practical workability are relevant to the precise specification of the rights that people have. ${ }^{140} \mathrm{In}$ addition, theories of the rights that people have (or do not have) may either abet or retard efforts to promote workability and efficiency, ${ }^{141}$ and may be judged either admirable or deficient on this basis.

Finally, the criterion of fit may respond to concerns of workability or efficiency insofar as notions of what a constitutional theory ought to fit, and how tightly, constrain denocratically sponsored efforts to promote those interests. Again, however, there is no absolute need to evaluate

138. See, e.g., Richard A. PoSner, Economic ANAlysis of LAw 675-752 (5th ed. 1998) (analyzing constitutional doctrines from an economic perspective); RICHARD A. PosNER, THE Economics of Justice 310-407 (1981) (same); Richard A. Posner, Free Speech in an Economic Perspective, 20 SuffolK U. L. REv. 1 (1986) (applying an economic model to free speech issues).

139. See BLACK, supra note 63, at 52-53 (asserting that "the most conspieuous function of judicial review may have been that of legitimizing rather than that of voiding the actions of government").

140. See, e.g., Richard H. Fallon, Jr., Individual Rights and the Powers of Government, 27 GA. L. Rev. 343, 352-53 (1993); T.M. Scanlon, Jr., Freedom of Expression and Categories of Expression, 40 U. PITT. L. REV. 519, 535-36 (1979).

141. Compare EPSTEIN, supra note 1, at 331-34 (defending a scheme of rights that generally accords with and promotes interests in economic efficiency), with RAwLs, supra note 74, at 61 (asserting that basic liberties cannot be sacrificed to promote economic interests). 
constitutional theories directly in light of interests in workability and efficiency, even if soinething is lost in the effort to subsume thein under other values. $^{142}$

Having defended the familiar evaluative criteria as capable of embracing most relevant concerns, I would identify just one further factor that ought to bear on the assessinent of coinpeting constitutional theories. This involves the relative acceptability of different theories to various members of the constitutional commumity and the relative likelihood that any particular theory might achieve broad acceptance.

Among the aspirations of constitutional theorizing is to identify fair and acceptable terms of cooperation among those-including but not limited to judges - who are involved in implementing the Constitution. ${ }^{143}$ The purpose of constitutional theory is largely justificatory. ${ }^{144}$ As a inatter of ideal, constitutional theory would furnish grounds for the exercise or nonexercise of judicial power that all affected parties could reasonably be expected to respect. ${ }^{145}$ In practice, the demand that everyone should actually coalesce on a constitutional theory, and accept it as justifying constitutional outcomes, is too stringent to be realistic, ${ }^{146}$ reasonable disagreenent is endemic to free societies. ${ }^{147}$ Nonetheless, agreement and even consensus should reinain as defiming aspirations for those engaged in constitutional argument. ${ }^{148}$ Justification, including constitutional justification, is principally a norniative concept, but one that cannot be divorced wholly from the

142. It might, of course, be suggested that interests in promoting the rule of law, democracy, and substantive rights could themselves be comprehended by some more overarching value, such as "justice" or "human welfare." The question then would be why it is plausible to judge constitutional theories on the basis of what are at most partial proxies or surrogates for this more ultimate value. The answer to this question may have much to do with contingent features of American constitutional theory and the need for rival constitutional theories to satisfy a descriptive test of fit. American constitutional theory is largely concerned with prescribing how courts shonld decide cases under the Amcrican Constitution, and under no descriptively plausible account do courts have a central role in ensuring overall distributive justice or in generally promoting human welfare. See generally CASs R. Sunstein, The Partial Constitution (1993) (discussing the limited set of problems that are either assigned by the Constitution to courts or are capable of effective judicial resolution).

143. See Richard H. Fallon, Jr., The Supreme Court, 1996 Term-Foreword: Implementing the Constitution, 111 HARV. L. REv. 56, 148-51 (1997).

144. See Strauss, supra note 69 , at $581,586$.

145. See Richard H. Fallon, Jr., Of Speakable Ethics and Constitutional Law: A Review Essay, 56 U. CHI. L. REv. 1523, 1548-49 (1989); see also DworkIn, LAw's EMPIRE, supra note 1, at 93 ("Law insists that force not be used or withheld, no matter how useful that would be to ends in view, no matter how beneficial or noble these ends, except as licensed or reqnired by individual rights and responsibilities flowing from past political decisions about when collective force is justified.").

146. See Fallon, supra note 145 , at 1548.

147. See, e.g., Amy Gutmann \& Dennis Thompson, Democracy and Disagreement 1 (1996); John Rawls, Political Liberalism 54-58 (1993).

148. See Fallon, supra note 145, at 1548-51; see also Michelman, supra note 1, at 1524-37 (discussing necessary conditions for judicial decisions to be experienced as consistent with selfgovernment). 
target audience of free and equal citizens at whom justification is aimed. ${ }^{149}$ Accordingly, all else being equal, a constitutional theory that offers better prospectsfor achieving broad acceptance should be preferred over a theory with poorer prospects.

\section{III}

Formal Theories, Substantive Criteria, AND the Pertinence of Who OCCupies the Bench

So far, I have argued that the selection of a constitutional theory should be based largely on instrumental grounds. Among theories satisfying a fit requirennent, the best will be that which most optimally proinotes mixed, weighted interests in the rule of law, political democracy, and appropriately specified substantive rights. No sooner are these criteria stated, however, than further questions arise about the kinds of constitutional theories to which they might be applied. Although Parts I and II of this Article emphasized a distinction between text-based and practice-based theories, constitutional theories can be categorized along a number of dimensions. Another axis of comparison, also highly pertinent in choosing a constitutional theory, divides substantive theories from theories that are more formal or methodological. Which of these two types of theories ought to be preferred?

The advantages of substantive theories are relatively straightforward. Since substantive theories prescribe decisions in accord with specified, substantive criteria, anyone who knows in advance what would count as "good" results can test substantive theories by their capacity to support her preferred pattern of decisions. By contrast, formal theories present an apparent puzzle: if an miportant test of constitutional theories involves their capacity to define and protect imdividual rights, how could it be desirable to adopt a theory with a predominant thrust that is methodological only? I suggest that proponents of formal theories must rely at least in part on predictions about the results that judges would reach under their approaches. Such reliance by no means inakes formal theorists unique, however. It is impossible to compare the relative virtues of competing constitutional theories without making predictions about who our judges and Justices are likely to be and about the kinds of decisions that they would nuake under alternative specifications of the judicial role.

\section{A. Substantive and Formal Theories}

Substantive theories advocate judicial decision making pursuant to criteria that aim to promote transparent substantive goals. Richard Epstein

149. Cf. RAwLs, supra note 147 , at $15,133-72$ (attempting to defend and justify political liberalism partly by reference to an "overlapping consensus" of views actually held by citizens of liberal democracies). 
provides an example. ${ }^{150}$ His book Takings presents a substantive theory, which he characterizes as reflecting natural law, ${ }^{151}$ that mixes libertarianism with economic efficiency analysis. ${ }^{152}$ Similarly, David Richards has propounded a theory under which judges should adjudicate constitutional issues in accord with Rawlsian liberalism. ${ }^{153}$

Unlike the approaches of Epstein and Richards, however, most constitutional theories tend to be more formal than substantive. ${ }^{154}$ Rather than prescribing decisions in accord with particular substantive values, formal theories generically identify the kinds of considerations that judges ought to weigh and dispute about the extent, if any, to which judges should make expressly normative judgunents. Originalists, for example, argue that judges generally should rest their decisions solely on the original understanding of the constitutional text. ${ }^{155}$ As I have suggested, most originalists believe that their methodology will tend to produce substantively attractive results. ${ }^{156}$ Nonetheless, in defending their theory, originalists treat the outcomes that originalism would yield as less important than the rule of law and political democracy. ${ }^{157}$ Indeed, it is not always obvious what results an originalist methodology would generate.

Proceeding in similarly abstract and methodological terms, Ronald Dworkin argues that judges should decide cases based on a theory that rationalizes both constitutional precedent and the constitutional text, and that depicts the relevant law in the best moral light, whatever that might be. ${ }^{158}$ Although Dworkin is a well-known liberal, he argues that it would be possible for a judge with conservative beliefs to use his methodological theory

150. See EPSTEIN, supra note 1.

151. See id. at 5, 304-05.

152. See id. at 5. For a critical exposition of Epstein's intermixture of these values, see Thomas C. Grey, The Malthusian Constitution, 41 U. MIAMI L. REv. 21 (1986).

153. See Richards, supra note 1. Epstein defends his theory as fitting the constitutional text, see Epsten, supra note 1, at 19-31, 304 (linking theory to text of the Eminent Domain Clause), while Richards defends his as fitting a mix of text and practice, see RICHARDs, supra note 1, at 283-90, 303-05. Each defends his theory as being consistent with the rule of law. See EPSTEIN, supra note 1, at 24-25; RICHARDS, supra note 1, at 282-305. In short, both for the most part attempt to fit the criteria of theoretical excellence discussed in Part II.

154. John Ely's theory, which calls for courts to imterpret open-ended constitutional provisions in such a way as to promote the functioning of political democracy, would also count as an exception to this gencralization if Ely's preferred conception of democracy were, by no means implausibly, characterized as a "substantive" value. Cf. ELY, supra note 1, at 75 \& n.* (acknowledging that the political "participation" protected by his theory "can obviously be regarded as a value" that judges ought to enforce).

155. See supra notes 17-20 and accompanyiug text. I say "generally" because of the need for originalism, in some cases, to accominodate precedent. See BoRK, supra note 1, at 155-59; SCALIA, supra note 7 , at $139-40$.

156. See supra notes $84-88$ and accompanying text.

157. See, e.g., BERGER, supra note 1, at 282-99, 351-96; BoRK, supra note 1, at 131 (arguing for adherence to the original understanding and characterizing liberal and conservative "revisionism" as "equally illegitimate").

158. See supra notes $30-33$ and accompanying text. 
to reach conservative results. ${ }^{159}$ In determining what would be the "best" light in which to cast the law, a conservative judge would draw on her conservative moral views.

To cite just one more example, at least some versions of constitutional "pragmatism"160 - which I shall refer to as "methodological pragmatism"are defined by the (negative) methodological claim that judges are not bound by any constitutional rules at all; ${ }^{161}$ liberated froin the restraints urged by other theories, judges should simply decide cases in whatever way will produce the best future results. ${ }^{162}$ In singling out methodological praginatism as a formal constitutional theory, I do not mean to claim that all versions of pragmatisin are inethodological rather than substantive. Nor do I deny that some advocates of methodological pragmatism have also offered substantive prescriptions or even general substantive theories. ${ }^{163}$ Judge Posner is a case in point. In some writings he has championed the position that judges should so decide cases as to promote wealth naximization. In his methodologically pragmatist work, however, Judge Posner has argued much more abstractly that judges should decide cases in whatever way will be best for the future; ${ }^{164}$ he specifically puts to one side the question of the criteria by which to measure what would count as "best."165 Methodological pragmatism, then, is a theory distinct from "wealth maximization" or from theories advancing other substantive claims under the "pragmatist" mantle. It consists in the bracing, distinctly methodological, starkly negative claim that judges are not bound by methodological rules.

The predominance of relatively formal constitutional theories is probably best explained by two considerations. First, anyone who adopts a

159. See, e.g., DWORKIN, FREEDOM's LAW, supra note 1, at 2-3 (arguing that the best constitutional methodology is one that "brings political morality into the heart of constitutional law," but that because the methodology can be used by both liberal and conservative judges, the methodology of furnishing a "moral reading" is "not, in itself, either ... liberal or . . conservative"); id. at 8 (distinguishing between the methodological claim that the Constitution should be given a "moral reading" and his "own interpretations" of what, substantively, would be the best moral reading); see also Edward J. McCaffery, Ronald Dworkin, Inside-Out, 85 CALIF. L. REv. 1043, 1046 (1997) (reviewing DWORKIN, FREEDOM's LAW, supra note 1) (distinguishing between "Dworkin's interpretive method, on the one hand, and his own particular instantiations of that [method] . . . on the other").

160. For an introduction to some of the varieties of pragmatism, see Symposium, 18 CARDozo L. REv. 1 (1996); Symposium on the Renaissance of Pragmatism in American Legal Thought, 63 S. CAL. L. Rev. 1569 (1990). For an explicit application of pragmatism to constitutional theory, see Daniel A. Farber, Legal Pragmatism and the Constitution, 72 MinN. L. REv. 1331 (1988).

161. See Richard A. Posner, Pragmatic Adjudication, 18 CARdozo L. Rev. 1, 4 (1996) (arguing that judges should make decisions "unchecked by any need to respect or secure consistency in principle with what other officials have done" or to follow other methodological rules).

162. See id.

163. See, e.g., PosNER, supra note 109, at 531-51; Farber, supra note 160, at 1366-74 (defending constitutional rights to abortion).

164. See POSNER, supra note 109, at 387-405; Posner, supra note 161, at 3-4.

165. See, e.g., Posner, supra note 161, at 16 ("I likewise lcave open the criteria for the 'best results' for which the pragmatic judge [should be] striving."). 
constitutional theory embraces a set of commitments against which she invites her own future arguments and actions to be tested for consistency and inconsistency, and possibility for dishonesty, fecklessness, or breach of trust. ${ }^{166}$ In this context, substantive theories inay call for a greater depth of precommitment than many participants in constitutional debates are conscientiously prepared to make. It is often difficult to specify in advance how far particular substantive ends should be pursued, and what attendant costs should be accepted, in varied and frequently unknown factual contexts. By contrast, it may be easier to subscribe to a decision procedure that reserves substantive judgment.

A second reason for the relative prominence of formal theories probably involves the perception that they, more than substantive theories, can be defended in terms likely to be persuasive with others. People who are motivated to reach agreement often find it easier to agree on fair procedures, or on lists of relevant criteria, than on an ordered set of substantive ends that would, once adopted, determine outcomes in previously disputed cases. ${ }^{167}$ This is not to deny that it is often easier to decide on correct results in particular cases than to determine what justifies those results at the level of theory. ${ }^{168} \mathrm{My}$ point is only that if we care about consensus on theoretical issues, it inay appear more promising to focus on relatively formal methodologies than to enter directly into a debate about substantive ends.

There are good reasons to seek theoretical consensus. As I have suggested already, theoretical consensus on fundamental issues is a goal that ought devoutly to be sought by anyone who cares about American constitutionalism. Reasonable commonality about argumentative premises and methodologies is necessary to maintain a sense of constitutional community within which disagreements can be experienced as reasonable, goodfaith disputes about the proper application of principles that, at some level of abstraction, are broadly shared. ${ }^{169}$ If constitutional reasoning is perceived as resting on partisan, parochial, or illegitimate premises, or as lacking 1nethodological integrity, its conclusions can only appear as alien impositions of force and will. .70 $^{170}$

Against the background of this threat, affirmations of reasonable forinal theories help to sustain conversation and to reinforce the sense that

167. See RAwLS, supra note 147, at 46 (arguing that abstraction of this kind "is a way of continuing public discussion when shared understandings of lesser generality have broken down").

168. See Cass R. Sunstein, The Supreme Court, 1995 Term-Foreword: Leaving Things Undecided, 110 HARV. L. REV. 4, 14-21 (1996).

169. See Fallon, supra note 145, at 1548-51; see also Michelman, supra note 1, at 1524-37 (discussing necessary conditions for judicial decisions to be experienced as consistent with selfgovernment).

170. Cf. Robert Cover, The Supreme Court, 1982 Term-Foreword: Nomos and Narrative, 97 HARV. L. REV. 4, 40-44, 53 (1983) (meditating on the "jurispathic" role of courts in rejecting beliefs woven into the normative order of minority communities and affirming that judges, in such contexts, are "people of violence"). 
there is enough common ground to make reasoned debate possible. Further, the tendering of a formal theory at least implicitly rejects the arguments of more rigid theories about the bounds of legitimate argument. Finally, advocacy of a formal theory constitutes an implied vow of argumentative seriousness and good faith. People's reasonable consistency in following their own avowed theories may help sustain a faith that constitutional practice imvolves a shared commitment to live by principle, and not by opportumism, sophistry, and manipulation.

Although there thus may be good reasons to endorse a relatively formal constitutional theory, it is important not to lose sight of the full set of criteria by which constitutional theories should be judged. For anyone choosing a constitutional theory, more is at stake than whether a particular theory will accommodate her own substantive views and uncertainties. To endorse a theory is to commend it to others, who might employ it to reach quite different conclusions, especially if the theory is a formal one that conteinplates a wide ambit for moral and political judgments. If constitutional theories should be evaluated based on their capacities to protect a morally acceptable set of mdividual rights, is it a plam imstake to endorse a formal theory, rather than insisting on a more substantive one?

The answer is "not necessarily."171 Other considerations aside, ${ }^{172}$ several mediating variables may help to indicate the practical implications of even comparatively formal theories. First, the more tightly a theory purports to cabin judgment, the easier it often will be to identify a theory's substantive consequences. For example, although further research may be required, it is relatively easier to identify the general substantive inplications of origmalism ${ }^{173}$ than of methodological pragmatism (to take just one more example).

Second, even with respect to formal theories that authorize expressly value-based judicial decision making, grounds for assessing substantive implications are by no ineans wholly lacking. Perhaps the most important variable is the character of those who are likely to occupy judicial

171. Cf. Fallon, supra note 143 (offering a relatively formal and practice-based theory that characterizes what judges within our constitutional practice appropriately do as attempting to implement the Constitution successfully, rather than searching for the "meaning" of the Constitution in every case); Fallon, supra note 10 (advancing a formal theory categorizing types of acceptable constitutional arguments and identifying their relationships to one another).

172. As noted above, a constitutional theory should be tested against interests in the rule of law and political democracy, as well as against the concern for substantive justice. With respect to the rule of law and political democracy, the implications of a formal constitutional theory may be relatively transparent, though perhaps not wholly free from historical contingency. For example, the realization of such rule-of-law norms as consistency and predictability may depend on the extent to which judges, at any particular time, share relevant values and understandings. See Fallon, supra note 72, at 49-50.

173. See Richard H. Fallon, Jr., The Political Function of Originalist Ambiguity, 19 HARv. J.L. \& PuB. PoL'y 487, 492 (1996) (characterizing originalism as "perhaps most often a political or rhetorical stalking horse for a set of substantive positions with respect to a relatively narrow set of constitutional issues in the current age"). 
office: what backgrounds, values, and foibles will judges bring to their deliberations, and how-for better or for worse-are their decisions likely to be affected? ${ }^{174}$ As scholars have emphasized, judges' relative insulation from the hurly-burly of politics may encourage them to view matters disinterestedly, in light of values that they think are or ought to be broadly shared. ${ }^{175}$ Nonetheless, judges' and Justices' personal values, backgrounds, and dispositions cannot be abstracted entirely from the picture. With enough general, probabilistic knowledge about who our judges and Justices are likely to be, it often may be possible to anticipate the pattern of judicial decisions even under theories that are both formal and relatively openended (such as Dworkin's theory or methodological pragmatism). ${ }^{176}$

Consideration of judges' likely backgrounds and values can also be relevant in forecasting results under purportedly more constraining formal theories, such as originalisin. Sophisticated originalists seldom claim that their method is perfectly determinate. ${ }^{177}$ According to Robert Bork, for example, the original understanding frequently yields no more than a value or a first premise, the application of which requires further judgment. ${ }^{178}$ In this act of judgment, a judge's sense of what is fair or otherwise desirable is likely to exert determining influence. ${ }^{179}$ Moreover, as others have einphasized, origimalist judges often may find that historical materials fail even to determine a uniquely correct rule or principle for judicial application. ${ }^{180} \mathrm{~A}$ particular difficulty involves the question whether historically

174. For provocative comment on these and related issues, see Mark Tushnet, Constitutional Interpretation, Character, and Experience, 72 B.U. L. REV. 747 (1992), and Paul Brest, Who Decides?, 58 S. CAL. L. REV. 661 (1985).

175. See, e.g., B1CKEL, supra note 1, at 23-28; Wellington, supra note 40, at 246-47. Without always being explicit about it, much of the neo-republican literature also appears to rest on this premise. See, e.g., Frank I. Michelman, The Supreme Court, 1985 Term-Foreword: Traces of SelfGovernment, 100 HaRv. L. REv. 4, 73-77 (1986); Cass R. Sunstein, Interest Groups in American Public Law, 38 Stan. L. Rev. 29 (1985).

176. Richard Posner draws on considerations such as these in arguing that judges authorized to do whatever they think best for the future will produce a desirable pattern of decisions as measured against virtually all relevant criteria:

Judges of the higher American courts are generally picked from the upper tail of population distribution in terms of age, education, intelligence, disinterest, and sobriety .... [A]t their best, American appellate courts are councils of wise elders and it is not completely imsane to entrust thein with responsibility for deciding cases in a way that will produce the best results in the circumstances rather than just deciding cases in accordance with rules created by other organs of government ..., although this is what they will be doing nost of the time.

Posner, supra note 161, at 11-12.

177. See Bork, supra note 1, at 162-63 (acknowledging that "two judges equally devoted to the original purpose" inay disagree about the results of constitutional cases).

178. See id.

179. Cf. Benjamin N. Cardozo, The Nature of the Judicial Process 12 (1921) (asserting that judges characteristically have "an underlying philosophy of life" including "inherited instincts, traditional beliefs, acquired convictions," and "a conception of social needs" that, "when reasons are nicely balanced, must determine where choice shall fall").

180. See TRIBE \& DORF, supra note 1, at 79-88 (framing the problem of determining the "level of generality" at which legal principles should be expressed); Brest, supra note 17, at 218-22 
contemplated applications of constitutional provisions conclusively determine constitutional "meanings."181 For example, Justice Scalia and Judge Bork have jousted over whether the First Amendnient protects only such speech as the framing generation specifically understood to be protected, or whether the origmal understanding should be expressed more abstractly as imvolving protection of all speech necessary to the effective functioning of the political process. ${ }^{182}$ Judgments about whether the "meaning" of constitutional provisions should be linked to specific historical expectations, or instead should be expressed in more abstract principles, often seem to reflect irreducibly moral or political assumptions. ${ }^{183}$ Finally, most originalists-including both Justice Scalia and Judge Bork-have recognized that courts must sometimes, but not always, accept the authority of judicial precedent that departs from the origmal understanding. ${ }^{184}$ Determining when precedent should be followed and when it should be rejected is an inherently value-laden task, ${ }^{185} \mathrm{~m}$ which a judge's moral and political beliefs nay often prove decisive.

\section{B. Historical Contingency and Constitutional Theory}

If information about judges is useful in gauging the practical implications of various constitutional theories, then information of this kind should also matter greatly in assessing rival theories' comparative attractiveness. Armed with predictions about how courts are likely to decide cases under alternative role specifications, we are better equipped to

(emphasizing "the indeterminate and contingent nature of the historical understanding that an originalist historian seeks to achieve").

181. See, e.g., Brest, supra note 17, at 220; Ronald Dworkin, Comment, in ScALla, supra note 7, at 115, 116-27; Mark D. Greenberg \& Harry Litman, The Meaning of Original Meaning, 86 GEO. L.J. 569 (1998) (arguing that the original understanding is crucial in determining meaning, but that original meaning should not be confused with origmal applications).

182. See Ollman v. Evans, 750 F.2d 970, $995-97$ (D.C. Cir. 1984) (Bork, J., concurring) (asserting that even if the Framers did not understand the First Amendment to restrict libel actions, courts should adapt doctrine to afford protection if libel actions have become a threat to "the central meaning of the First Amendment" as measured by the original understanding); id. at 1038-39 (Scalia, J., dissenting in part) (rejecting an approach that permits doctrinal "evolution" in light of changed sociological conditions). Others have suggested that the First Amendment was originally understood to protect substantially less speech than either Judge Bork or Justice Scalia has contemplated. See, e.g., Michael J. Perry, Interpretivism, Freedom of Expression, and Equal Protection, 42 OHIO ST. L.J. 261, 287 (1981) (asserting that the Framers and ratifiers of the First Amendment "at most ... intended it to prohibit any system of prior restraint and to modify the common law of seditious libel") (citations omitted).

183. See TrIBE \& DORF, supra note 1, at 65-80, 97-117 (arguing that judicial value judgment cannot be avoided in identifying the level of generality at which constitutional rights should be specified).

184. See BORK, supra note 1, at 155-59; SCALIA, supra note 7, at 139-40.

185. Cf. BORK, supra note 1 , at 158 (observing that the question when to follow non-originalist precedent is "addressed to the prudence of a court"); SCALIA, supra note 7, at 140 (acknowledging that "I cannot deny that stare decisis affords some opportunity for arbitrariness-though I attempt to constrain my own use of the doctrine by consistent rules"). 
assess which theories will do better, and which worse, at realizing the rule of law, political democracy, and substantive rights.

That the anticipated capacities and characters of judges are relevant to constitutional theory is undoubtedly a familiar point. Perhaps no one has ever thought otherwise. To my mind, however, this banality has implications that are not always, or perhaps even widely, recognized.

To begin with, there is no reason to think that the character and quality of judges, and their relative capacities to make sound judgments of political morality, will be historical constants. ${ }^{186}$ The judges of one era may tend to be more parochial in outlook, or more thoughtful and deliberative, than the judges of another. Judicial appointments and attendant judicial tendencies may be more crassly politicized in some times than in others. ${ }^{187}$ The federal judiciary of one period may have accepted an agenda that accords with substantive justice and that lends itself to successful judicial implementation, whereas the judiciary of another era may cling to quixotic aspirations that defy consistent implementation. ${ }^{188}$

If the choice of constitutional theories is aimed at achieving the best realization of imterests im the rule of law, democracy, and individual rights, it may be a imistake to assume that there is one best constitutional theory for all time. ${ }^{189}$ Just as the nature of the judiciary may change, so may the surrounding character of American politics and the orientation of dominant political movements toward both the Constitution and substantive justice. As changes occur, the constitutional theory that would work best to satisfy the relevant criteria in one era inay not work best im another.

It may help to be slightly more concrete. Many New Deal liberals espoused a constitutional theory that demanded great judicial deference to politically accountable decisionmakers. ${ }^{190}$ Adhering to such a theory, Felix Frankfurter found himself frequently out of step with the Warren Court,

186. See Tushnet, supra note 174, at 756-63 (contrasting the Court that decided Brown v. Board of Education, and the range of experiences of its members, with the current Justices and their range of experiences).

187. Cf. Scalia, supra note 7 , at 46 (arguing that processes of judicial appointment and decision have become increasingly politicized and are likely to continue to be so).

188. The Supreine Court of the Lochner era furnished a prominent example of the latter phenomenon. The defining doctrines of that era not only rested on normatively dubious premises, but also contained "seeds of self-contradiction," LAURENCE H. TRIBE, AMERICAN CONSTITUTIONAL LAW 574 ( 2 d ed. 1988), that made consistent enforcement impossible, see id. at 567 (noting that "more statutes in fact withstood due process attack" during the Lochner era "than succumbed to it"); see also id. n.2. By contrast, the Court led by John Marshall successfully implemented a nation-building agenda that subsequent generations have widely applauded. See, e.g., ROBERT G. MCCLOSKEY, THE AMERICAN Supreme Court 54-80 (1960); William Bennett Munro, The Makers of the UnWritten CONSTITUTION 53-81 (1930).

189. Cf. PAUL W. KAHN, Legitimacy AND History (1992) (describing four "models" of constitutional discourse and decision making that have developed in response to challenges presented by different constitutional eras).

190. See ANDREW L. KaufMaN, CARDOZo 534 (1998). 
whose implicit constitutional theory defined the judicial liberalism of another age. ${ }^{191}$ Perhaps New Deal deference can be reconciled with Warren Court activism based on differences between the defining constitutional issues of the two eras. ${ }^{192}$ But it is also possible that a constitutional theory prescribing judicial deference to the political branches was appropriate for the New Deal era, in which democratically validated experiment was necessary to respond to econormic emergency and advance substantive justice, but was not right for the Warren era, in which historical forces made the federal judiciary an apt and possibly necessary instrument of reform. ${ }^{193}$ Or maybe the value-based decision making of the Warren era violated appropriate, formal limits on the judicial role, and formally similar value-based decision making by the Rehnquist Court is justified today both to correct depredations wrought by the Warren Court and to restore substantive coherence to the law.

Whatever conclusion anyone might reach, possibilities such as these cannot be dismissed out of hand. Some degree of instrumental calculation becomes inescapable once it is recognized that competing constitutional theories should be assessed under criteria that refer not only to the rule of law and democracy, but also to acceptably specified individual rights.

\section{Meeting an Objection}

My suggestion that which constitutional theory is "best" may depend on historically relative considerations, including the varying character of the judiciary, invites an obvious and formidable objection: even if the circumstances of adjudication change and the quality of the judiciary varies, it does not follow that people should alter their constitutional theories based on shifting instrumental calculations. Rather, it might be said, anyone ought to adopt whatever theory would be best for all of constitutional time, taking into account that the chosen theory should be applied across diverse historical circumstances by judges and Justices who differ in quality and normative outlook.

191. See Wallace Mendelson, The Influence of James B. Thayer upon the Work of Holmes, Brandeis, and Frankfurter, 31 VAND. L. REV. 71, 80 (1978).

192. Cf. ELY, supra note 1, at 73-75 (arguing that the Warren Court's agenda largely involved correcting defects in the political process and that its approach was not inconsistent with a plilosophy counseling judicial deference in cases not involving process defects).

193. Cf. Archibald Cox, The Role of the Supreme Court in American Government 35 (1976):

In the 1930s a modest view of the judicial function in constitutional interpretation fitted the new generation's desire for progressive social and economic reform. The legislative and executive branches were engaged in the redistribution of power and the protection of the disadvantaged and distressed. By the 1950 s the political atmosphere liad clianged. The legislative process, even at its best, became resistant to libertarian, humanitarian, and egalitarian inpulse. At worst, the legislatures became repressive, in the libertarian view, because of the Cold War, increased crime, the fear of social disorder, and, perhaps, the strength of established economic and political power. 
Although offering the apparent advantage of principled constancy, this view loses plausibility when tested against the long and continuing history of American constitutionalism. Our constitutional system is organized around a text-much of it written in highly general language- that is difficult to amend by formal means and that has attained near sacred status in the surrounding culture. ${ }^{194}$ Within a constitutional tradition such as ours, it is both natural and desirable that courts should assume different stances toward the written constitutional text, and its interpretation, at different times. Professor Kahn, for example, has argued that whereas the Supreme Court of the John Marshall era viewed the Constitution as the reflection of political scientific insights that the Court should also strive to implement, ${ }^{195}$ subsequent generations found the political assumptions of the Framers and ratifiers to be imcreasingly alien and constitutional norms to be mcreasingly needful of interpretation, adaptation, and extension. ${ }^{196}$ As the constitutional community's relation to the written Constitution changed, Kahn argues, interpretive methodology also changed ${ }^{197}$-as I, among many others, ${ }^{198}$ believe that it should.

Sone, notably the originalists, resist the notion that interpretive nethodology should alter over time. As Justice Scaha pithily puts it, the "whole purpose" of the Constitution is to "prevent change,"199 or at least to make change difficult. In particular, Article $\mathrm{V}$ specifies a stringent mechamism for constitutional amendment. ${ }^{200}$ But while Justice Scalia resists the notion that the methodology of constitutional adjudication should ideally evolve,

194. For a provacative elaboration of the idea that the Constitution functions as the central text in an American "civil religion," see SANFORD Levinson, Constitutional FAITH (1988).

195. See KAHN, supra note 189, at 23-31.

196. See id. at 46-133.

197. See id. at 23-170.

198. According to Lawrence Lessig, for example, it becomes necessary for constitutional interpreters of remote generations to "translate" the meaning of principles endorsed by the Constitution's Framers and ratifiers in order to apply those principles faithfully and sensibly in contexts that the parties to the original understanding never contemplated. See Lessig, supra note 1, at 1211-47; Lawrence Lessig, Understanding Changed Readings: Fidelity and Theory, 47 STAN. L. REv. 395, 44672 (1995).

199. SCALIA, supra note 7 , at 40 .

200. See U.S. CoNST. art. V (requiring that constitutional amendments be proposed by either two-thirds of both Houses of Congress or by a Convention called by two-thirds of the states, and that they be ratified by three-fourths of the states). For arguments that the mechanism provided in Article $V$ is not exclusive, see 1 ACKERMAN, supra note 1, at 44-45; 2 ACKERMAN, supra note 1, at 69-95, 115; Akhil Reed Amar, The Consent of the Governed: Constitutional Amendment Outside Article V, 94 ColUM. L. Rev. 457 (1994); Akhil Reed Amar, Philadelphia Revisited: Amending the Constitution Outside Article V, 55 U. CHI. L. REv. 1043, 1054 (1988). The views of Professors Ackerinan and Amar have been sharply criticized, however, and it remains the "orthodox" view, 2 ACKERMAN, supra note 1, at 115, that the Article V mechamism is exclusive. See, e.g., Fried, supra note 109, at 17-33; Laurence H. Tribe, Taking Text and Structure Seriously: Reflections on Free-Form Method in Constitutional Interpretation, 108 HARV. L. REV. 1221, 1280-86 (1995). For valuable discussion of a variety of issues involving the practice of constitutional amendment, see RESPONDING TO IMPERFECTION: THE THEORY and Practice of Constitutional Amendment, supra note 26. 
even he accepts that constitutional theory must adapt in practice. ${ }^{201}$ Many entrenched doctrines depart from original understandings; 202 governinental structures and private expectations have taken root in non-originalist precedent. ${ }^{203}$ Under the circuinstances, Justice Scalia acknowledges that courts must develop a theory that accommodates the timeless originalist ideal with respect for stare decisis. ${ }^{204}$

Another consideration supports the view that the attractiveness of constitutional theories inay be historically relative. The project of implementing the Constitution, through adjudication and otherwise, is inherently collective; coordination is needed to achieve the benefits of the rule of law, effective political democracy, and the enjoyment of an acceptable regine of rights. ${ }^{205}$ In these circumstances, to endorse a constitutional theory is to commend it to others, with reasonable hope that some will accept the theory as a basis for coordinated decision making. In offering commendation, the proponent of a constitutional theory should act on sincerely held values. Nonetheless, a crucial aim of constitutional theorizing is to identify interpretive principles that others can reasonably be asked to accept. ${ }^{206} \mathrm{As}$ the historical context changes, so will the relative plausibility of alternative theories as "focal points" for widespread acceptance and coordinated action. ${ }^{207}$ And as changes occur in various theories' prospects for gaining acceptance, so may the relative attractiveness of the theories theinselves.

\section{IV \\ Who NeEds Constitutional ThEORY?}

Claims such as these may appear to verge on constitutional, or at least constitutional theoretical, nihilism. If the best constitutional theory nay vary from era to era, why should it not also vary froin case to case? Indeed, if the justifications for adopting a constitutional theory are substantially instrumental-aimed at proinoting the rule of law, democracy, and substantive justice-why not simply dispense with constitutional theory

201. See Scalia, supra note 7, at 139-40 (characterizing a theory of stare decisis as "a pragmatic exception to" his originalist philosophy).

202. See supra note 60 and accompanying text.

203. See BoRK, supra note 1 , at 158.

204. See ScAlia, supra note 7, at 139-40.

205. See Fallon, supra note 143, at 148-51.

206. See id. at 109-10 (arguing that "the ideal of constitutional law requires willingness among those charged with implementing the law to accept reasonable, if not always ideal, premises as bases for coordinated decisionmaking").

207. The concept of "focal points," referring to potential solutions to coordination or other problems that, for cultural or psychological reasons, are peculiarly salient and thus especially capable of supporting agrecments and coordinated behavior, originated with THOMAS C. SCHELLING, THE STRATEGY OF CONFLICT 58-80 (1960). On the relevance of focal points to constitutional theory, see Fallon, supra note 143, at 110; and Strauss, supra note 1, at 910-13. 
altogether and decide each case in whatever way would best promote those ultimate values?

This Part responds to these challenges. Against the claims of methodological pragmatists, I maintain that judges and Justices can better serve underlymg values if they accept norms of the kind that traditional constitutional theories defend. I then argue that although judges and Justices need not expressly choose a constitutional theory, neither can they avoid theoretical commitments. In giving reasons for their decisions, judges and Justices necessarily rely on assumptions about the methods of reasoning that courts ought to pursue. For a judge or Justice to appeal to inconsistent assumptions from one case to the next would breed cymicism. The ideal of judicial reason, as distinct from power or will, implies an obligation of methodological integrity.

\section{A. The Perils of Pragmatism}

The suggestion that there is no need for constitutional theoryconceived as a set of prescriptions that should apply unvaryingly to all constitutional cases (whether within or across constitutional eras)-is by no ineans an idle one. This is essentially the claim of inethodological praginatism, as chainpioned by Judge Richard Posner and others. ${ }^{208}$ According to Judge Posner, courts should decide each case in the way that will have the best consequences, "unchecked by any felt duty to secure consistency in principle with what other officials have done in the past"209 or to adhere to other methodological rules that are more constraining than an open-ended charge to do what is "best" for the future. ${ }^{210}$

In assessing the challenge of methodological pragmatists, it is important to keep in mind that inethodological pragmatism is itself a constitutional theory, ${ }^{211}$ which competes with other theories in its clainis about how judges should decide cases. Accordingly, inethodological praginatism should be tested against the saine criteria as other, more traditional theories. The relevant question is whether the current state of affairs, in which the prescriptions of more traditional theories are at best unevenly observed, would be inproved if methodological pragmatism achieved broad adherence.

In my view, acceptance of methodological pragmatism would make things worse, not better. In offermg traditional theories, theorists implicitly clain that, by realigning current practices in specified ways, we could more fully realize soine mixture of values associated with the rule of law,

\footnotetext{
208. See, e.g., Posner, supra note 1; Posner, supra note 161; Farber, supra note 160.

209. Posner, supra note 161 , at 4 .

210. See id. at 4, 15-16.

211. Cf. Posner, supra note 1, at 10 (characterizing Cass Sunstein's theory-which is discussed infra at notes 215-220 and accompanying text-as an "anti-theory").
} 
democracy, and individual rights. By inviting judges to act on their personal views of what would make the future better, pragmatism would authorize judicial behavior that offends both rule-of-law and democratic values; it would also devalue the notion of a constitutional "right."212 Pragmatists can, of course, reply that judges should take these considerations into account in determining what would be best for the future, all things considered. ${ }^{213}$ Pragmatist judges might therefore follow established rules except where it would be very costly to do so, and they might write disingenuous opimions purporting to accept the authority of past decisions even when they were really setting out in new directions that they thought better for the future. In my view, however, basic assumptions underlying both political democracy and the rule of law require judicial truth-telling. ${ }^{214}$ Even if a general norm of truth-telling could somehow be pragmatically justified, I would regard it as a mistake to trust judges with explicit discretion to do whatever they thought best and to endow their judgments with the majority-trumping force of constitutional law.

\section{B. Do Judges Need Constitutional Theory?}

A related argument against traditional constitutional theory focuses specifically on whether constitutional theory is valuable to judges. As Cass Sunstein points out, the Supreine Court has never made an "official choice" among competing theories. ${ }^{215}$ Arguing "[a]gamst theories, [a]gainst rules," 216 Sunstein maintains that judges are unlikely to have any special aptitude for theory. ${ }^{217} \mathrm{He}$ further asserts that we are frequently likely to get better decisions if Supreme Court Justices resolve issues on a case-specific, shallowly theorized basis. ${ }^{218}$ According to Sunstein, the Court should avoid entangleinent with large, confusing, and often divisive abstractions, such as the claims of constitutional theories. ${ }^{219}$

212. See Dworkin, LAw's EMPIRE, supra note 1, at 152 ("Pragmatism . . denies that people ever have legal rights; it takes the bracing view that they are never entitled to what would otherwise be worse for the community ....").

213. See id. ("Pragmatists have an explanation ... of why the language of rights and duties figures in legal discourse. They argue, on pragmatic grounds, that judges must sometimes aet as if people had legal rights, because acting that way will serve society better in the long run.").

214. See David L. Shapiro, In Defense of Judicial Candor, 100 HARv. L. REV. 731, 746-47, 750 (1987) (observing that paternalistic dissembling would be unacceptable to the public and that judicial candor is necessary to measure judges' fidelity to law).

215. Sunstein, supra note 168 , at 13.

216. Id. at 14.

217. See Cass R. Sunstein, Legai Reasoning and Political Conflict 46 (1996) (citing the "limited capacities of judges" as a reason why constitutional adjudication should generally turn on "low-level principles" rather than abstract, general theories).

218. See id. at 35-48.

219. See id. at 171-82; cf. id. at 56-57 ("Judges should adopt a presumption rather than a taboo against high-level theorization."). 
I agree with Professor Sunstein that a judge does not need a fully articulated theory in order to do her job. ${ }^{220} \mathrm{~A}$ judge or Justice can proceed case by case. Indeed, in the best tradition of the common law, she inay have good reason to avoid theoretical commitments that may prove untenable in liglit of events and arguments that she cannot foresee. Nonetheless, a judge's work cannot be innocent of constitutional theory, nor can a judge escape obligations of theoretical consistency.

For a judge as much as for anyone else, it is impossible to engage in constitutional argument without making at least implicit assumptions about appropriate methodology. ${ }^{221}$ For example, to adopt an argument based on precedent is to presuppose the validity of a theory that makes precedent at least relevant and possibly controlling. Theoretical commitments are also implied when a judge or Justice either appeals to the original understanding or rejects such appeals.

Moreover, in offering arguments that reflect theoretical assumptions, participants in constitutional debates assume obligations of consistency. ${ }^{222}$ Suppose that Justice A, dissenting in one case, argues that the Supreme Court is bound to follow the original understanding of constitutional language, but that Justice A herself refuses to be bound by the original understanding im another case. Or suppose that Justice B criticizes Justice A for deciding an unnecessary constitutional issue, but then herself decides an unnecessary issue im a subsequent case. Unless the cases are persuasively distinguishable, Justices A and B have both fallen short of professional ideals. Judicial mconsistency affronts the rule of law. A substantive imjustice may also occur if relevant similar cases are treated differently. More insidiously, a failure of judges and Justices to behave consistently may breed a destructive, spiraling cynicism. The practice of constitutional adjudication depends for its integrity on an assumption of good faith:

There must be a sense that [judges and Justices with opposing views] are advancing legal arguments because they believe in them deeply and not as a stratagem for imposing their will on the law. There must be a sense that reasons matter more than results. The power to imterpret carries the responsibility of good faith and selfdenial. When these are destroyed, nothing remains but counting votes and the exercise of raw power. ${ }^{223}$

220. Indeed, as Sunstein points out, “Justices O'Connor, Kennedy, Souter, Ginsburg, and Breyer"- arguably "the analytical heart of the current Court"- have not subscribed individually to any readily identifiable interpretive methodology. Sunstein, supra note 168 , at 14.

221. See DworkIN, LAw's EMPIRE, supra note 1, at 90; Fallon, supra note 10, at 1234-35.

222. See GutmanN \& Thompson, supra note 147, at 81-82 (arguing that "civic integrity" requires "consistency im speech" and "consistency between speech and action").

223. Edward Lazarus, Closed Chambers 249 (1998). 
Again, by suggesting that judges and Justices have obligations of methodological consistency, ${ }^{224}$ I do not imply that each needs to, or indeed should, begin by endorsing a comprehensive constitutional theory. I do mean to claim, however, that issues of constitutional theory are unavoidable, especially for judges. Every judge and Justice therefore needs at least parts of a constitutional theory, even if not a complete one. Commitments to theoretical tenets occur willy-nilly in the decision of cases. ${ }^{225}$

\section{$\mathrm{V}$ \\ QUESTIONS ON THE AGENDA}

Even if the agenda of constitutional theory remains vital, for judges as much as for the rest of us, troubling questions arise once we recognize that theoretical approaches must be assessed partly on predictive or instrumental grounds. These mclude questions about the appropriate time horizon to consider in choosing and advocating a constitutional theory (for anyone disposed to do so explicitly) and about who should make the choice under conditions characterized by reasonable disagreement. I shall offer only brief comments on these questions, which I take up in reverse order.

\section{A. Who Should Choose?}

Under current circumstances, the choice of a constitutional theory must be made by individual participants in constitutional debates. The People of the Umited States have not made an authoritative decision in this matter, nor has the Supreme Court. Within reasonable bounds, the People of the United States, by constitutional amendment, could prescribe a constitutional theory to be applied by courts (and other officials). I recognize that there is soinething paradoxical about this claim. Obvious questions are, first, what theory should courts use in interpreting the hypothesized amendment asserting that they should follow particular interpretive practices and, second, how could the choice of that logically prior theory be

224. The obligation of consistency is necessarily provisional and defeasible. The constraints established by constitutional theory are justified by reference to what I have called "legitimacy criteria," but, as I have noted, the legitimacy criteria themselves are always subject to challenge within the practice of constitutional law. See supra text accompanying note 75. As a result, the characteristic methodology of constitutional theory must be one analogous to Rawls's concept of "reflective equilibrium," see RAwLs, supra note 74, at 20-22, in which an acceptable balance is sought among the specification of relevant legitimacy criteria, a constitutional theory or methodology, and the consequences of application of the constitutional theory in any particular case. The felt unacceptability of a particular outcome can, in principle, always trigger a reassessment and possibly a readjustment of anyone's theory, and a matching change in the specification of applicable legitimacy criteria, which would result in a new reflective equilibriun.

225. See Ronald Dworkin, In Praise of Theory, 29 ARIz. ST. L. J. 353, 354 (1997) ("In practice, you cannot think about the correct answer to questions of law unless you have thought through or are ready to think through a vast over-arching theoretical system ...."). 
justified? Isn't the effort to establish the validity of any interpretive theory subject to a problem of infinite regress? ? $^{226}$

In response to questions such as these, I agree that appeal must ultimately be made to anterior conventions, practices, and norms, some of which transcend, and cannot themselves be justified by, positive law. I assume, however, that the relevant practices mclude those of linguistic usage, within which a constitutional amendment's central applications can be largely incontrovertible. I also assume that strong normative arguments, rooted in premises about the fair allocation of political power, would support respecting the dictates of relatively contemporaneous Constitution-amending supermajorities. As matters now stand, however, the People of the Umited States have not recently (or historically, for that matter) established a clear set of interpretive rules that are binding on courts.

If a Supreme Court majority should ever hold that the Constitution requires a particular interpretive theory, its ruling would also bind the lower courts. But the Court's decision, while "final," would not therefore be infallible; it would remain open to dissenting Justices and critics to protest that the Court had erred and to seek reversal of its mandate. Again, however, although the Justices sometimes engage in expressly constitutional theoretical debates, ${ }^{227}$ the Court has not formally endorsed any single theory. ${ }^{228}$

Amid the flux of current practice, the choice of a constitutional theory has what Ronald Dworkin characterizes as an irreducibly "protestant" aspect. $^{229}$ Among the constitutional theories that flt acceptably well with the constitutional text or prevailing practice, each person must decide for herself which would best promote the rule of law, political democracy, and substantive justice. But if choice is im one sense protestant, the decision also has a collective or communal focus. ${ }^{230}$ The project of implementing

226. Cf. Stanley Fish, DoING What CoMEs NATuRally 121 (1989) (arguing that because "rules are texts," which "are in need of interpretation," they "cannot themselves serve as constraints on interpretation").

227. See, e.g., Planned Parenthood v. Casey, 505 U.S. 833, 846-53, 951-53 (Rehnquist, C.J., dissenting), 979-81 (Scalia, J., dissenting) (1992) (involving disputes about the standards for legitimate decision-making under the "substantive" aspect of the Due Process Clause and about the requirements of stare decisis); Michael H. v. Gerald D., 491 U.S. 110, 122-30 (plurality opinion), 132 (O'Connor, J., concurring), 137-41 (Brennan, J., dissenting) (1989) (disputing the role of tradition in substantive due process adjudication).

228. See Sunstein, supra note 168 , at 13 .

229. DwORKIN, LAW's EMPIRE, supra note 1, at 413 (associating law with "a protestant attitude that makes each citizen responsible for imagining wliat his society's public commitunents to principle are, and what those commitinents require in new circumstances").

230. For criticism of Dworkin's theory of law on the gronnd that it is excessively protestant in its characterization of the judicial role and pays insufficient heed to law's collective and communal aspects, see Richard H. Fallon, Jr., Reflections on Dworkin and the Two Faces of Law, 67 NoTRE DAME L. Rev. 553, 559-66 (1991). 
the

Constitution, and thereby realizing the rule of law, political democracy, and protection of substantive rights, is inherently a shared one, ${ }^{231}$ which requires coordinated action based on mutually acceptable premises. All else being equal, one theory should therefore be preferred to another if it is more consonant with widely-shared values or has better prospects of attaining broad acceptance. ${ }^{232}$

\section{B. What Are the Appropriate Time Horizons?}

Although the choice of a constitutional theory should be partly instrumental, it should not be crassly opportunistic. The aspiration is to establish the best attainable terms of cooperation in a collective enterprise. Too many changes of position in a short time span would frustrate, rather than promote, interests in fostering cooperativeness, promoting respect for judicial decisions as the outconie of fair and reasoned deliberative processes, and sustaining the rule of law. ${ }^{233}$

The question of appropriate time horizons is therefore an important one, but one that can only be addressed in generalities. At a minimum, the frame of reference needs to be broad enough to separate overarching issues concerning the judicial role from interests in securing the optimal outcome in any particular case or set of cases. This distinction is far from crisp. Nonetheless, it situates constitutional theory where it ought to be situated: reinoved from the abstract philosophical enterprise of seeking pure, timeless, moral, and political truths, but separated also from the issue-byissue posturing and trading that often characterize partisan, electoral politics. In evaluating and endorsing constitutional theories, anyone should be

231. See Fallon, supra note 143, at 148-51.

232. Cf. id. at 109-10 (arguing that coordination interests in constitutional law provide a powerful reason to accept "the result best situated to win majority acceptance as a reasonable accommodation of competing considerations").

233. The interest in fostering cooperativeness raises the question whether, in abandoning a constitutional theory for substantially instrumental reasons, anyone-especially a judge or a Justice of the Supreme Court-should feel obliged to acknowledge those reasons candidly in defending a chosen alternative. My inclination is to believe that reasons should be given, and that the reasons given must be honestly believed, but that if these standards are met, it nay not always be necessary to make public acknowledgement of all relevant reasons. See Shapiro, supra note 214, at 736 ("The problem of [judiciall candor ... arises only when the individual judge writes or supports a statement he does not beheve to be so."). Taking a somewhat more stringent position, Professor Monaghan has suggested that a judge, in writing an opinion, has an obligation to refer to all motivating considerations: "[i]f justifications cannot be stated in the opinion, they should not be relied upon in entering the judgment." Henry P. Monaghan, Taking Supreme Court Opinions Seriously, 39 MD. L. REv. 1, 25 (1979). In my view, however, it should suffice for a judge or Justice to announce that she has rejected a constitutional theory because, in light of experience, it had become clear that the theory (if generally followed) would be inferior to some other theory in satisfying mixed, weighted interests in promoting the rule of law, political deinocracy, and individual rights. I see no need-in this case or more generally-for a judge or Justice to state every intermediate premise on which she relies in applying a publicly acknowledged and defended standard to reach a publicly stated conclusion. 
prepared to accept at least some unwanted practical implications of her own, conscientiously developed theory. ${ }^{234}$

\section{CONCLUSION}

We should assess constitutional theories in light of their capacity to promote the rule of law, political democracy, and a scheme of individual rights consonant with substantive justice. The last of these criteria, im particular, is substantive rather than formal. For those who would choose a constitutional theory, ultimate questions of political morality therefore cannot be avoided. But neither can the choice of a constitutional theory occur solely by reference to ideals. A crucial practical question is how any particular theory would probably be employed-for good or for ill-by those who are likely to be judges in particular historical contexts.

In light of the complexity of the issues on which choice of a constitutional theory appropriately depends, many will wish to avoid opting definitively for one theory and renouncing all others. They will imstead prefer a case-by-case approach, similar to that of common law judges. This can indeed be a responsible stance. Nonetheless, taking positions on issues of constitutional theory is ultimately unavoidable. It is impossible to engage im constitutional argument without making methodological assumptions. Moreover, anyone who engages im good-faith argumentation assumes obligations of methodological consistency. The enterprise of constitutional justification requires consistent application of fair standards of valid argument.

To recognize that a constitutional theory should be chosen partly on instrumental grounds is, therefore, not to license unprincipled manipulations. Once adopted, a constitutional theory ought to impose constraints on those who accept it. Nonetheless, it would reflect a deep mistake-a misunderstanding of what constitutional theory is for-not to evaluate constitutional theories based on the results that they are likely to produce.

234. On the circumstances under which the results prescribed by a theory might be so unacceptable as to trigger a reconsideration and possibly a rejection of the theory itself, see supra note 224. 
